\title{
Petrographical and geochemical changes in Bosnian stalagmites and their palaeo-environmental significance
}

\author{
Veronica Chiarini $^{1,2^{*}}$, Isabelle Couchoud ${ }^{2,3}$, Russell Drysdale ${ }^{2,3}$, Petra Bajo ${ }^{3}$, \\ Simone Milanolo ${ }^{4,5}$, Silvia Frisia ${ }^{6}$, Alan Greig ${ }^{7}$, John Hellstrom ${ }^{7}$, and Jo De Waele ${ }^{1}$ \\ ${ }^{1}$ Department of Biological, Geological and Environmental Sciences (BIGEA), University of Bologna Alma Mater, Italy \\ ${ }^{2}$ Laboratoire EDYTEM, UMR CNRS 5204, Université Savoie Mont Blanc, Le Bourget du Lac, France \\ ${ }^{3}$ School of Geography, University of Melbourne, Australia \\ ${ }^{4}$ Hydro Engineering Institute Sarajevo - HEIS, Sarajevo, Bosnia and Herzegovina \\ ${ }^{5}$ Center for Karst and Speleology - CKS, Sarajevo, Bosnia and Herzegovina \\ ${ }^{6}$ Earth Sciences, SELS, The University of Newcastle, NSW Australia \\ ${ }^{7}$ School of Earth Science, University of Melbourne, Australia
}

\begin{abstract}
Detailed petrographic observations have been coupled with trace element and $\delta^{13} \mathrm{C}-\delta^{18} \mathrm{O}$ analyses in order to investigate their dynamics in two Holocene Bosnian speleothems. The potential of this multiproxy approach in providing a means to extract palaeo-environmental information from stalagmites whose stable isotope signals are noisy and without obvious trends has been tested. The studied stalagmites are mostly characterized by columnar microcrystalline fabric. At the sub-millimetre scale of lamination, different microcrystalline columnar sub-types (open and closed) have been detected and classified on the basis of the observed porosity and the crystallite size. The presence of variations in crystallite arrangement at the lamina scale suggests the occurrence of small-scale environmental changes recorded in the studied samples. A positive correlation was found found between $\mathrm{Mg}$ concentration, $\delta^{13} \mathrm{C}$ and fabric variations, while a negative correlation relates those parameters with $\mathrm{Sr}$ concentration. Both $\delta^{13} \mathrm{C}$ and fabric changes appear to be directly related to changes in hydrology. The detailed observation of calcite fabrics combined with stable isotope and trace element profiles allowed for the interpretation of the conditions under which the speleothems were deposited.
\end{abstract}

Keywords: $\quad$ speleothems, stable isotopes, trace elements, calcite fabrics, microstratigraphy

Received 9 August 2016; Revised 28 December 2016; Accepted 30 December 2016

Citation: $\quad$ Chiarini V., Couchoud I., Drysdale R., Bajo P., Milanolo S., Frisia S., Greig A., Hellstrom J. and De Waele J., 2017. Petrographical and geochemical changes in Bosnian stalagmites and their paleoenvironmental significance. International Journal of Speleology, 46 (1), 33-49. Tampa, FL (USA) ISSN 0392-6672 https://doi.org/10.5038/1827-806X.46.1.2057

\section{INTRODUCTION}

Stalagmites are considered excellent continental materials for the study of past climate changes thanks to their formation in a relatively stable environment, protected from erosion and weathering processes, and to the possibility of obtaining precise ages with the U-Th disequilibrium technique. Oxygen and carbon stable isotope ratios are the most commonly used climate and environmental proxies extracted from stalagmites (e.g., McDermott, 2004; Fairchild \& Baker, 2012). The interpretation of the climate signal relies on the assumption that carbonate precipitation and stable isotope fractionation occurred under equilibrium conditions. This condition has been routinely validated with the Hendy test (1971). However, this test presents some limitations (e.g., Dorale et al., 2002; Spötl \& Mangini,
2002; Couchoud, 2008; Dorale \& Liu, 2009; Lachniet, 2009). In fact, there are cases in which stalagmites apparently affected by disequilibrium fractionation still preserve climate signals (e.g., Dorale \& Liu, 2009; Lachniet, 2009; Kennett et al., 2012; Ridley et al., 2015). In addition, even stalagmites influenced by disequilibrium isotope fractionation, which occurs more frequently than previously thought, can indirectly provide information about climate and environmental changes, as disequilibrium conditions can be triggered by factors related to climate (e.g., Hellstrom et al., 1998; Plagnes et al., 2002; Genty et al., 2006; Lachniet, 2009).

The fabric of stalagmites (i.e., the shape and arrangement of the calcium carbonate crystals) changes under different physical and hydrochemical conditions, and provides additional information on the environment of formation. This can facilitate the 
interpretation of the stable isotope signal (e.g Frisia et al., 2000; Couchoud, 2006; Frisia \& Borsato, 2010; Mattey et al., 2010; Belli et al., 2013; Riechelmann et al., 2014; Frisia, 2015). According to Frisia (2015), the speleothem fabric is a useful, complementary tool to recognise the presence, and evaluate the intensity, of disequilibrium isotopic fractionation. For example, calcite fabric and the $\delta^{13} \mathrm{C}$ signal can constrain interpretations because this isotopic ratio is more responsive to conditions associated with local soil $\mathrm{CO}_{2}$ production and hydrology. In particular, driprate variations influence the duration of degassing, which can result in enrichment in ${ }^{13} \mathrm{C}$ in the solution covering the stalagmite (Dreybrodt, 1988; Usdowski \& Hoefs, 1990).

The most recent and comprehensive speleothem calcite fabric classification has been proposed by Frisia (2015). It reports a methodology for fabric identification and for the sequential coding of fabrics, reflecting, in a hierarchic system, the conditions of precipitation: drip rate, supersaturation, $\mathrm{Mg} / \mathrm{Ca}$ ratio, and the presence of impurities in the feeding waters. The coded fabrics can then be plotted along with the other geochemical geochemical parameters on a timeor depth scale of the speleothem.

In this study, we examined two stalagmites found already broken in Mračna Pećina Cave (Bosnia and Herzegovina). We carried out a detailed petrographic study and combined these with trace element and stable isotope measurements to explore the possibility of extracting palaeo-environmental signals from samples that present high-variability (i.e., noisy) stable isotope profiles that apparently lack trends that might be interpretable in terms of past climate changes.

\section{STUDY SITE}

Mračna Pećina (also known as Banja Stijena) is a relatively small cave located on the left flank of the narrow valley cut by the Prača River (ca. $45 \mathrm{~km}$ East of Sarajevo, Republika Sprska, Bosnia and Herzegovina, Fig. 1). The cave was discovered at the beginning of the $20^{\text {th }}$ century; an artificial entrance and concrete stairs were built between the First and Second World War to allow tourists to access the first chamber (Daneš, 1921). The artificial entrance is located at $597 \mathrm{~m}$ a.s.1., about $20 \mathrm{~m}$ above the Prača River, at the foot of a limestone cliff. The natural entrance, now occluded by a rockfall, is located on the north-eastern upper side of the first chamber, not far from the artificial entrance $\left(43^{\circ} 46^{\prime} 20.534^{\prime \prime} \mathrm{N}\right.$; $18^{\circ} 53$ '14.049” E).

The cave has developed at the foot of the Romanija Plateau, which reaches the highest elevation of 1500 $\mathrm{m}$ a.s.1. in its western part, while the central and southern parts overlying the cave reach elevations between 800 and 1,000 $\mathrm{m}$ a.s.1. The Romanija massif consists of a Triassic succession of basal sandstone followed by massive limestone with ammonites, crinoids, and lenses of dolomite, reef limestone and light grey limestone with megalodonts and dolostone. The Mračna Pećina Cave network develops in the Triassic massive limestone and is characterised by a W-E orientation, coherent with a major thrust line that separates the massive reef limestone from the massive limestone containing ammonites and dolomites. The cave comprises a chamber $10 \mathrm{~m}$ wide and up to $6 \mathrm{~m}$ high, decorated with stalactites and flowstones, and located close to the entrance. A series of galleries totalling $1,148 \mathrm{~m}$ in length occurs on the same principal level, with a total depth with respect to the entrance of $37 \mathrm{~m}$. In the entrance area, a dark coating is ubiquitous on the cave walls, and is probably related to the use of torches during tourist visits at the beginning of the last century.

Nowadays, the surface above the cave is modified due to grazing and timber cutting (Milanolo et al., 2013). Evidence of human occupation and activities in the area dates back to the Neolithic period (Srejovic, 1994). The plateau is characterised by conifer-dominated woods and pastures, while the valley where the cave entrance is located hosts deciduous vegetation. The present-day climate is temperate, with warm summers and cold and snowy winters. Rainfall is distributed all year round with the absence of a distinct dry season. Annual precipitation in the Sarajevo region reaches $946 \pm 160 \mathrm{~mm}$, while mean annual temperature is $11.0 \pm 0.7^{\circ} \mathrm{C}$ (for the time interval 1992-2015; Sarajevo meteorological station, Federal Institute of Hydrometeorology $\mathrm{BIH}$; Fig. 2).

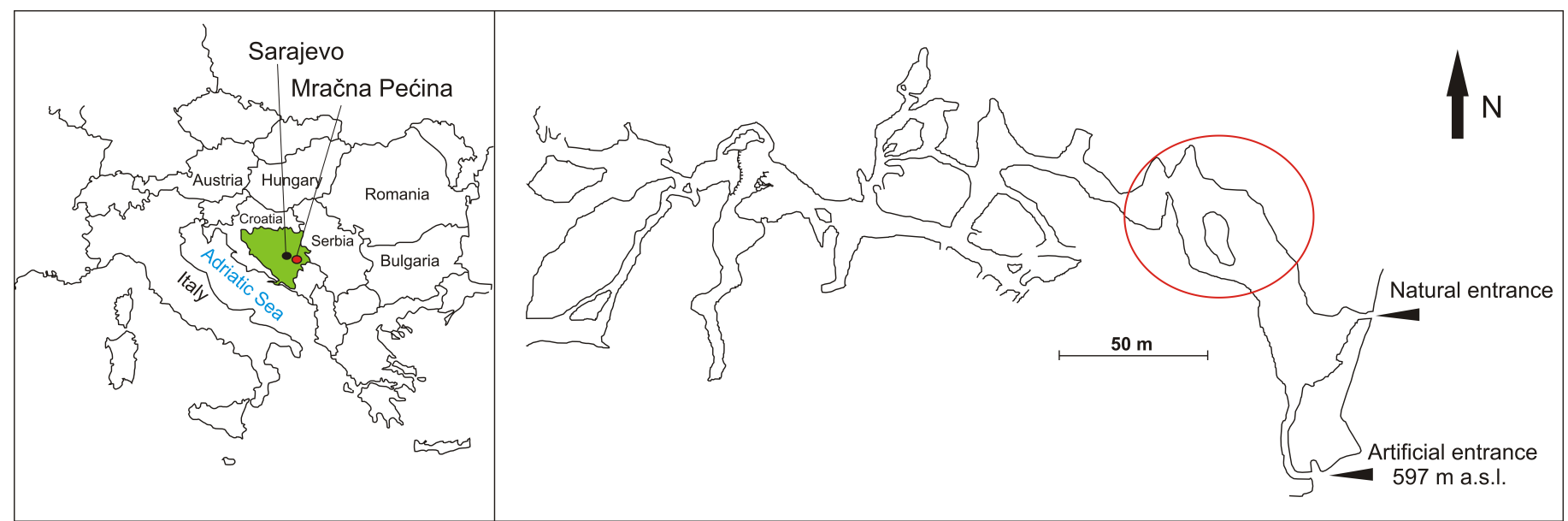

Fig. 1. Left: Map of Bosnia and Herzegovina, and location of the capital city, Sarajevo and Mračna Pećina Cave; Right: Mračna Pećina Cave map. The red circle indicates the area where the stalagmites were collected. 


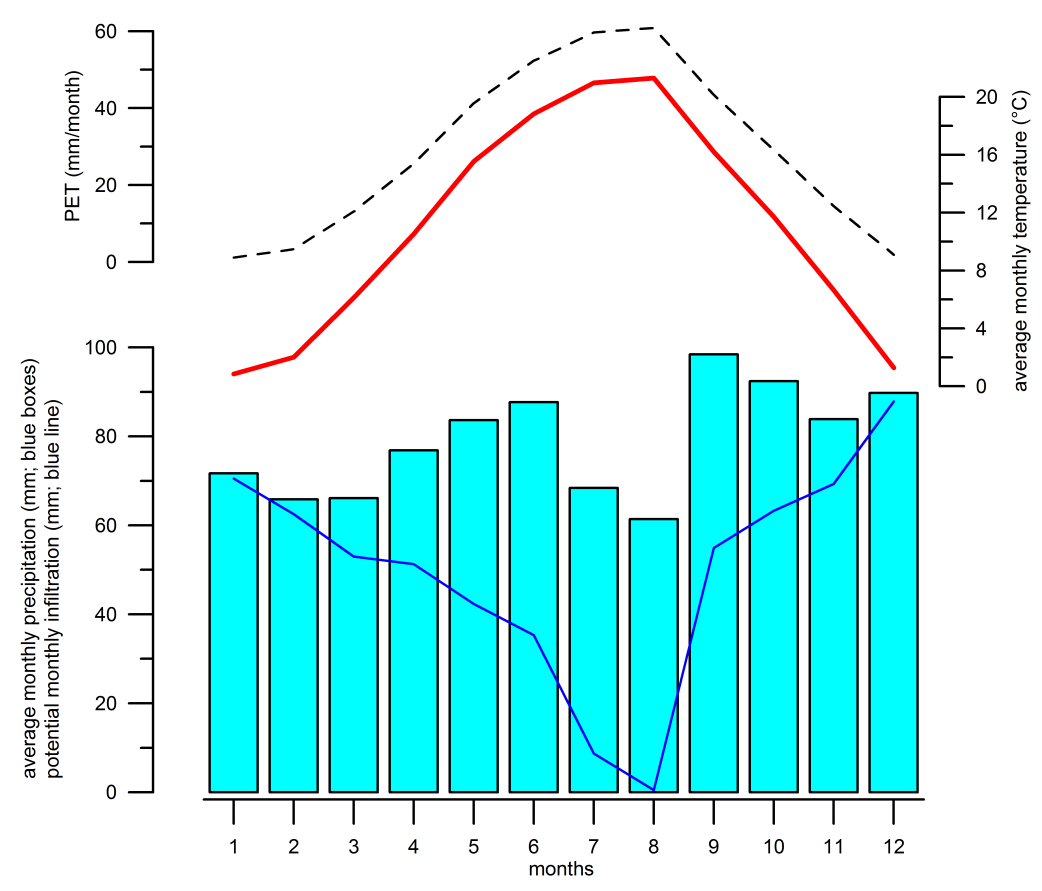

Fig. 2. Average monthly precipitation (blue boxes: time interval 1992-2015); potential monthly infiltration (blue line); average monthly temperature (red line: time interval 1992-2015) and potential evapotranspiration (PET; black dotted line). PET was calculated using average monthly temperature in the Thornthwaite \& Mather (1957) equation; potential infiltration was estimated as the difference between precipitation and PET. Data from the Sarajevo weather station, Federal Institute of Hydrometeorology (Bosnia and Herzegovina).

\section{MATERIALS AND METHODS}

\section{The sampled stalagmites}

The two stalagmites examined in this study (BS14 and BS15) were found already broken near the main chamber (between 50 and $100 \mathrm{~m}$ from the artificial entrance). Although it has not been possible to reconstruct their original position, the presence of a dark coating on their surfaces, similar to the one deposited on the cave walls and other stalagmites in this area, suggests the broken specimens were lying close to their original positions in the cave. They are both characterised by a flat and regular lamination and by a squat shape $(\mathrm{BS} 14: 9 \mathrm{~cm}$ tall and average diameter of $7.5 \mathrm{~cm}$; BS15: $10 \mathrm{~cm}$ tall and average diameter of $6.5 \mathrm{~cm}$ ) (Fig. 3). Preliminary dating was performed with the U/Th method at the University of Melbourne (School of Earth Science). Uranium and thorium were separated from the bulk of the carbonate matrix through a procedure involving the dissolution of the sample and addition of a mixed spike that enables to constrain the yield of the procedure. The uranium and thorium of the spiked samples were extracted by elution through TRU-Spec columns. Ages have been corrected using a $\left({ }^{230} \mathrm{Th} /{ }^{232} \mathrm{Th}\right)_{\mathrm{i}}$ of $0.30 \pm 0.20$ for BS14 and $0.65 \pm 0.19$ for BS15, which have been calculated according to the stratigraphic approach described in Hellstrom (2006). The results show that these stalagmites grew during the later half of the Holocene (from $\sim 6$ to $\sim 2 \mathrm{ka}$ for BS14 and from 4 to $1 \mathrm{ka}$ for BS15; see Table 1 ).

\section{Stable isotope analyses}

Samples for $\delta^{13} \mathrm{C}$ and $\delta^{18} \mathrm{O}$ analyses were drilled along the vertical growth axis at a $1 \mathrm{~mm}$ increment. About
$2 \mathrm{mg}$ of powder were collected for each sample using a $1 \mathrm{~mm}$ diameter drill bit mounted on a MicroProto systems MicroMill 2000. Samples designed for the Hendy test (Hendy, 1971) were drilled every 3 to $5 \mathrm{~mm}$ along each of three distinct laminae on each stalagmite using a $0.6 \mathrm{~mm}$ diameter drill bit (see sampling tracks in Fig. 3).

All carbonate isotope samples were prepared and analysed at the School of Geography, University of Melbourne. For the growth-axis samples, about 0.7 to $0.8 \mathrm{mg}$ of powder were weighed into glass vials, which were purged with helium before sample acidification using $105 \% \mathrm{H}_{3} \mathrm{PO}_{4}$ at $70^{\circ} \mathrm{C}$. The sample $\mathrm{CO}_{2}$ gas was then carried into an Analytical Precision AP2003 continuous-flow isotope-ratio mass spectrometer using an ultra-high-purity (99.9995\%) helium carrier gas. External reproducibility was better than 0.05 and $0.10 \%$ o for $\mathrm{C}$ and $\mathrm{O}$, respectively. For the Hendy test samples, about 0.05 to $0.10 \mathrm{mg}$ of calcite powder were weighed and placed in glass vials and analysed on a Nu Instruments Perspective dual-inlet isotope-ratio mass spectrometer. The samples were acidified with $105 \% \mathrm{H}_{3} \mathrm{PO}_{4}$ at $70^{\circ} \mathrm{C}$ in a $\mathrm{Nu}$ Instruments NuCarb sample preparation unit and the sample gas $\mathrm{CO}_{2}$ admitted into the ion source under vacuum.
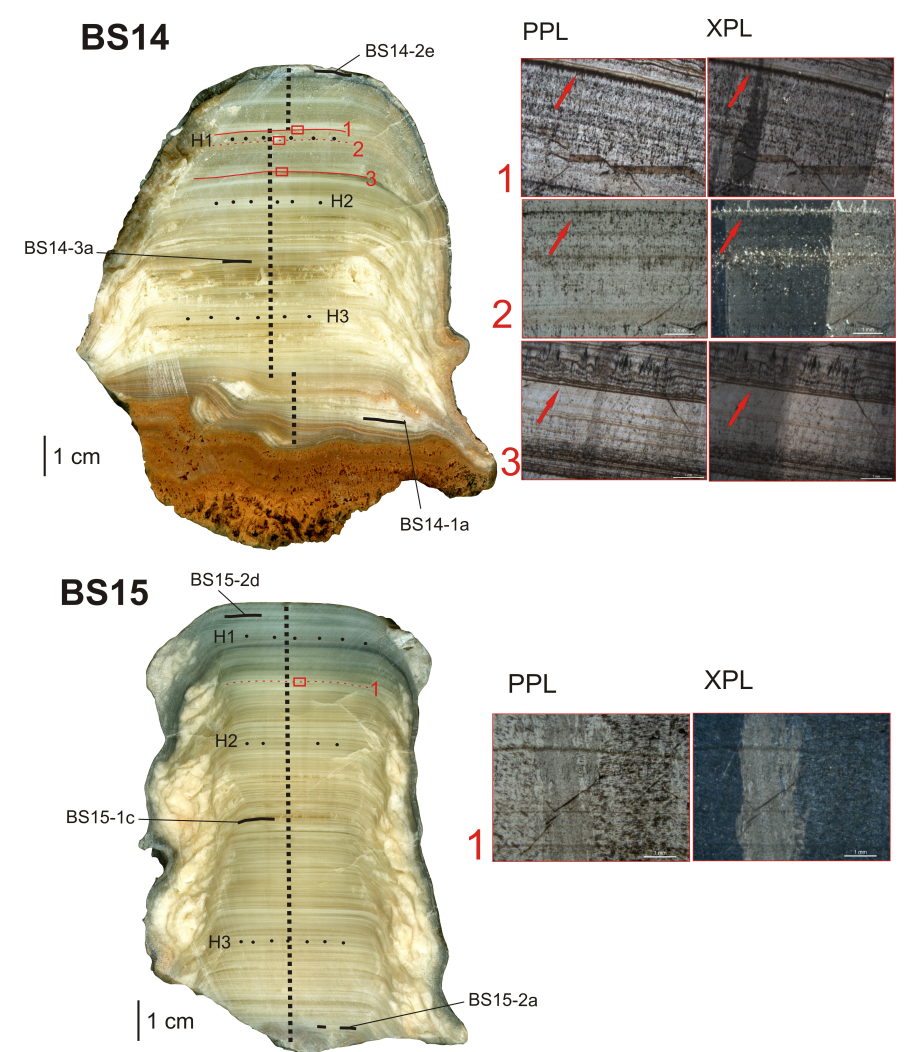

Fig. 3. Polished sections of stalagmites BS14 and BS15 showing U-Th and stable isotope samples. Dating used calcite powder sampled with a micromill along laminae (black segments). The vertical lines along the central stalagmite axes represent the stable isotope tracks. $\mathrm{H} 1, \mathrm{H} 2$, and $\mathrm{H} 3$ indicate the laminae where the Hendy tests were performed (Fig. 8). Red lines indicate hiatuses in BS14 (surfaces 1 and 3). The red dotted line on BS14 (2) and on BS15 (1) indicates possible short hiatuses. On the right, photos of thin sections taken over each of these growth discontinuities, in plane polarised light $(\mathrm{PPL})$ and cross polarised light (XPL). 


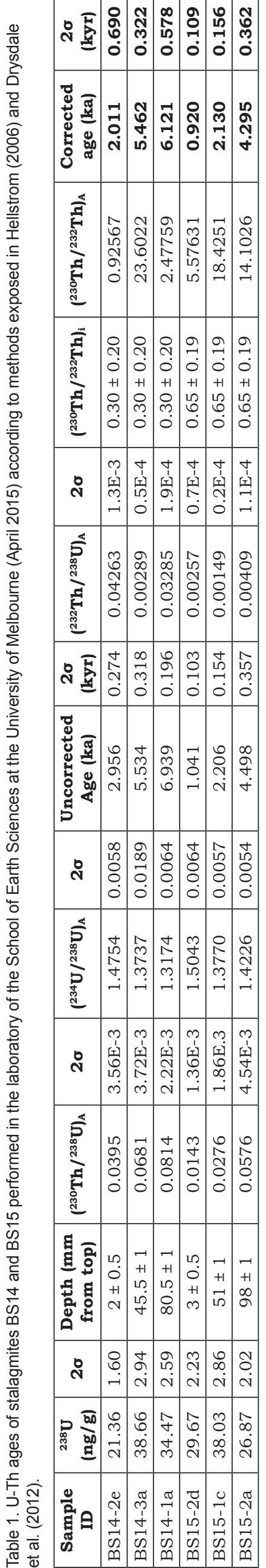


External reproducibility was 0.03 and $0.06 \%$ for $\mathrm{C}$ and $\mathrm{O}$, respectively. Sample data from both instruments were normalised to the V-PDB scale using two inhouse calcite standards (a Carrara Marble standard, 'NEW1', and a powdered homogeneous calcite prism of unknown origin, 'NEW12'), both previously calibrated against the international reference standards NBS-18 and NBS-19.

\section{Trace element analyses}

Trace element concentrations were analysed continuously along the vertical growth axis of stalagmite BS15 at the School of Earth Sciences (University of Melbourne) by a Helex laser-ablation system, equipped with a customised Resonetics Resolution $193 \mathrm{~nm}$ ArF laser system, in conjunction with an Agilent 7700x quadrupole ICP-MS instrument, as described in Woodhead et al. (2007) and Drysdale et al. (2012). The polished speleothem surface was pre-ablated with a 188- $\mu \mathrm{m}$-diameter laser spot at an intensity of $10 \mathrm{~Hz}$ in order to eliminate surface contamination. A $8 \times 140 \mu \mathrm{m}$ laser slit and a pulse rate of $10 \mathrm{~Hz}$ was used for the analysis, which was carried out in a high purity helium atmosphere. One continuous track has been performed at the velocity of $30 \mu \mathrm{m} / \mathrm{s}$, covering the entire length of stalagmite BS15. In order to compare the data with the isotopic values and conform the statistical analyses, an average value for each element has been calculated at a millimetre interval corresponding to the stable isotope profiles. Correlation coefficients have been calculated between individual trace elements and between the trace element and stable isotope values.

\section{Petrography}

Both stalagmites were cut along their vertical growth axis. The two halves were polished and subsequently scanned at high resolution for stratigraphic observation. Two thin sections containing the full length of both stalagmites were made. Petrography was studied on an Olympus BH-2 BHS polarising microscope. Pictures of magnified thin sections were taken with a Leica MC 120 HD camera mounted on the microscope.

Growth discontinuities were identified and calcite textures were recognised and classified following the criteria proposed in Frisia (2015). At the scale of lamination, calcite crystallite size was inferred on the basis of: 1) the composite crystallite boundary geometries, from which intracrystalline microporosity has been deduced; and 2) intercrystalline porosity features (i.e., pore orientation and geometry and their relative distribution). From this, a sub-classification scheme for the columnar microcrystalline texture was constructed for this case study. Following the hierarchical classification of fabrics proposed by Frisia (2015), a ranking has been associated with each fabric subtype that expresses a progressive increase of inter- and intra-crystalline porosity within the microcrystalline subtypes, which is related to the presence of impurities directly affecting the crystallite lattice development. In addition, by analogy with the calcite classification proposed in Frisia (2015), which was considered as a starting point for this specific subdivision, the deposition of the classified textures under increased hydrological stress (i.e., less regular dripping) is inferred, which may also have influenced the stable isotope fractionation of the precipitated calcite.

\section{Statistical analyses used for comparing petrography and geochemical signals}

Each petrography class was examined on the basis of calcite stable isotope and trace element composition to investigate the possible presence of geochemical signatures. In order to test whether isotopic variations are associated with petrographic changes, a Kruskall-Wallis test was performed. An isotope-fabric plot (IsoFab) was built according to the method described by Frisia (2015), calculating the average $\delta^{13} \mathrm{C}$ and $\delta^{18} \mathrm{O}$ values for each fabric and the associated standard deviations. In order to investigate the statistical significance of isotopic differences/ similarities between the petrography groups, multiple comparisons using the Bonferroni correction have been performed (e.g., Dunn, 1961). Finally, to further investigate the presence of geochemical signatures in the classified petrography groups, discriminant analysis was performed using SPSS IBM software ${ }^{\circledR}$, considering first the $\delta^{13} \mathrm{C}$ and $\delta^{18} \mathrm{O}$ composition of petrography classes in stalagmites $\mathrm{BS} 14$ and $\mathrm{BS} 15$, then $\delta^{13} \mathrm{C}, \delta^{18} \mathrm{O}, \mathrm{Sr}$, and $\mathrm{Mg}$ composition (e.g., Green et al., 2008). Indeed, this particular multivariate analysis allows for the attribution of single individuals to different groups according to chosen variables. These variables are used to construct canonical discriminant functions as a function of which individuals are plotted.

\section{RESULTS}

\section{Stable isotope profiles $\left(\delta^{13} \mathrm{C}\right.$ and $\left.\delta^{18} \mathrm{O}\right)$}

The stable oxygen isotope profiles in both samples do not have any evident long-term trend and are dispersed in the same range of values $\left(B S 14 \delta^{18} \mathrm{O}\right.$ mean value: $-8.0 \pm 0.4 \%$; $\mathrm{BS} 15 \delta^{18} \mathrm{O}$ mean value: $-8.1 \pm 0.3 \%$; Fig. 4). Conversely, $\delta^{13} \mathrm{C}$ values are much more dispersed in the BS14 record than in $\mathrm{BS} 15$ (BS14 $\delta^{13} \mathrm{C}$ mean value: $-8.4 \pm 1.0 \%$; $\mathrm{BS} 15 \delta^{13} \mathrm{C}$ mean value: $-9.4 \pm 0.4 \%$ o). While $\mathrm{BS} 14$ shows no evident trend, a long-term trend towards higher $\delta^{13} \mathrm{C}$ values is evident in the upper half of BS15, starting at $40 \mathrm{~mm}$ from the top (Fig. 4).

Stable oxygen and carbon isotope fluctuations show a statistically significant correlation in stalagmite BS14 $\left(r^{2}=0.466\right)$, suggesting that calcite precipitation likely occurred under disequilibrium conditions (Hendy, 1971). In stalagmite BS15, stable oxygen and carbon isotope values show no significant correlation $\left(r^{2}=0.095\right)$, suggesting that precipitation possibly occurred closer to isotopic equilibrium (although equilibrium conditions are unlikely in most cave environments; Mickler et al., 2006 and references therein). To support this first inference, we performed the Hendy test on a few laminae: 

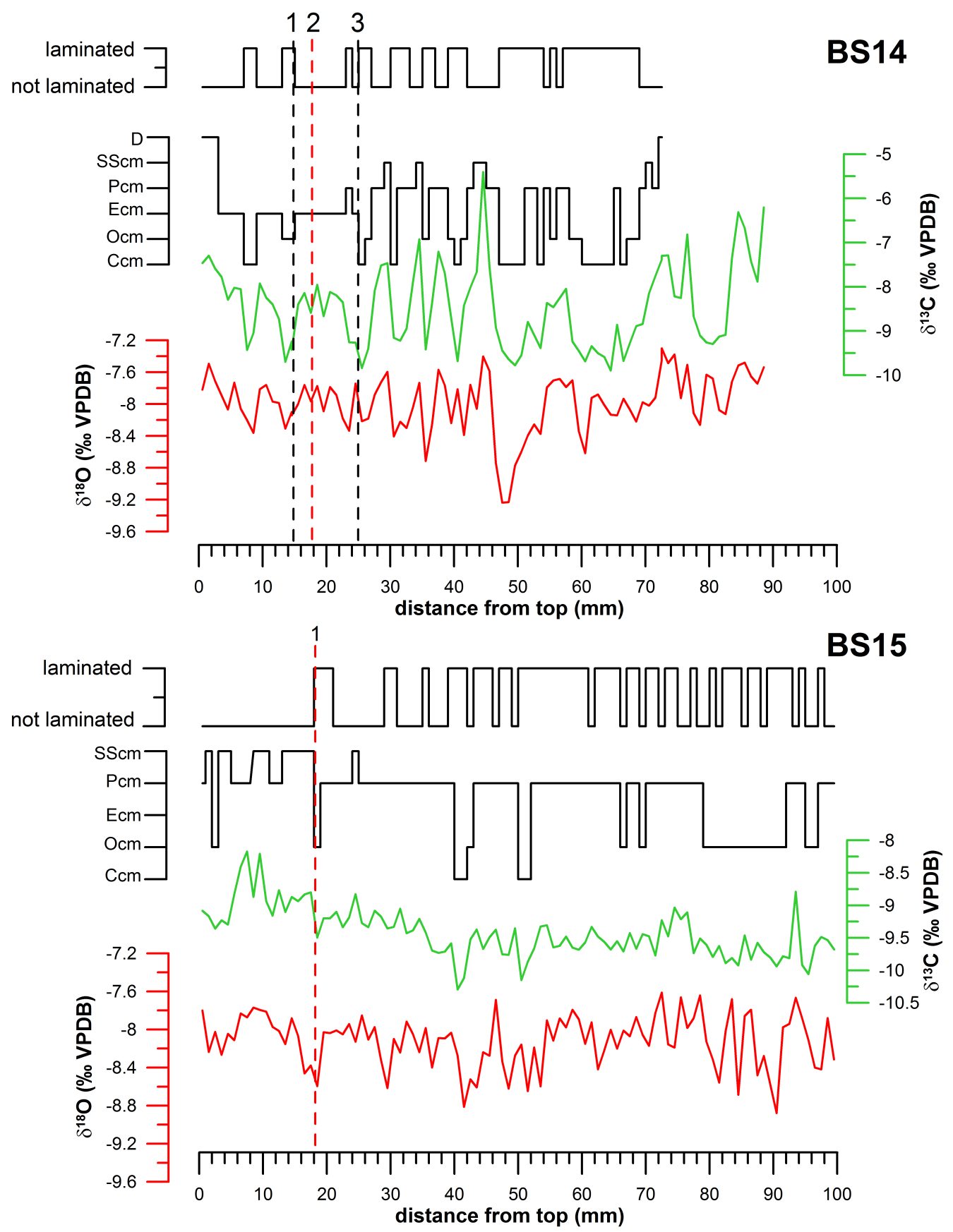

Fig. 4. Stable $\delta^{13} \mathrm{C}$ (green line), $\delta^{18} \mathrm{O}$ (red line), petrography micrologging and colloid-derived lamination in stalagmites BS14 and BS15. Dotted lines indicate the recognised (black) and possible (red) hiatuses in stalagmites BS14 and BS15.

- BS14 stalagmite:

The samples along the lamina at $59 \mathrm{~mm}$ from the top (H3 in Fig. 5) show a lateral enrichment of $0.86 \%$ for $\delta^{13} \mathrm{C}$ and of $0.51 \%$ o for $\delta^{18} \mathrm{O}$, suggesting significant disequilibrium fractionation. The two laminae sampled at 31.5 and $16.5 \mathrm{~mm}$ from the top $(\mathrm{H} 2$ and $\mathrm{H} 1$ in Fig. 5) show a smaller lateral variation in stable isotope values $\left(0.32 \%\right.$ and $0.13 \%$ for $\delta^{13} \mathrm{C}$ and $0.17 \%$ and $0.26 \%$ for $\delta^{18} \mathrm{O}$, respectively) pointing to a lower degree of disequilibrium fractionation in this portion.

- BS15 stalagmite:

Variations along the laminae at $79 \mathrm{~mm}$ and 32.5 $\mathrm{mm}$ from the top are comparable $(0.20 \%$ and $0.16 \%$ for $\delta^{13} \mathrm{C}$ and $0.17 \%$ and $0.26 \%$ or $\delta^{18} \mathrm{O}$, respectively; $\mathrm{H} 3$ and H2 in Fig. 5). Samples from the lamina at $8 \mathrm{~mm}$ from the top show stronger fluctuations for $\delta^{13} \mathrm{C}$ values (range of $0.62 \%$; $\mathrm{H} 1$ in Fig. 5) while $\delta^{18} \mathrm{O}$ values are more stable (range of $0.18 \%$ ), suggesting the possible occurrence of prolonged $\mathrm{CO}_{2}$ exchange with the cave air related to long residence time of a thin film of fluid at the growing stalagmite surface in this portion of the stalagmite (Dreybrodt \& Scholz, 2011; Hansen et al., 2013).

\section{Trace element concentration in stalagmite BS15}

Trace elements were analysed by laser ablation only in stalagmite BS15. However, only the calculated average values at the millimetre scale have been considered for this study (Fig. 6). This choice was made to enable consistent comparisons amongst the proxies (i.e., trace elements, petrography and stable isotope profiles).

Correlation coefficients were calculated between each analysed element in order to support graphic observations (Table 2). Among divalent cations ( $\mathrm{Sr}$, $\mathrm{Ba}$, and $\mathrm{Mg}$ ), the results show a strong covariation 

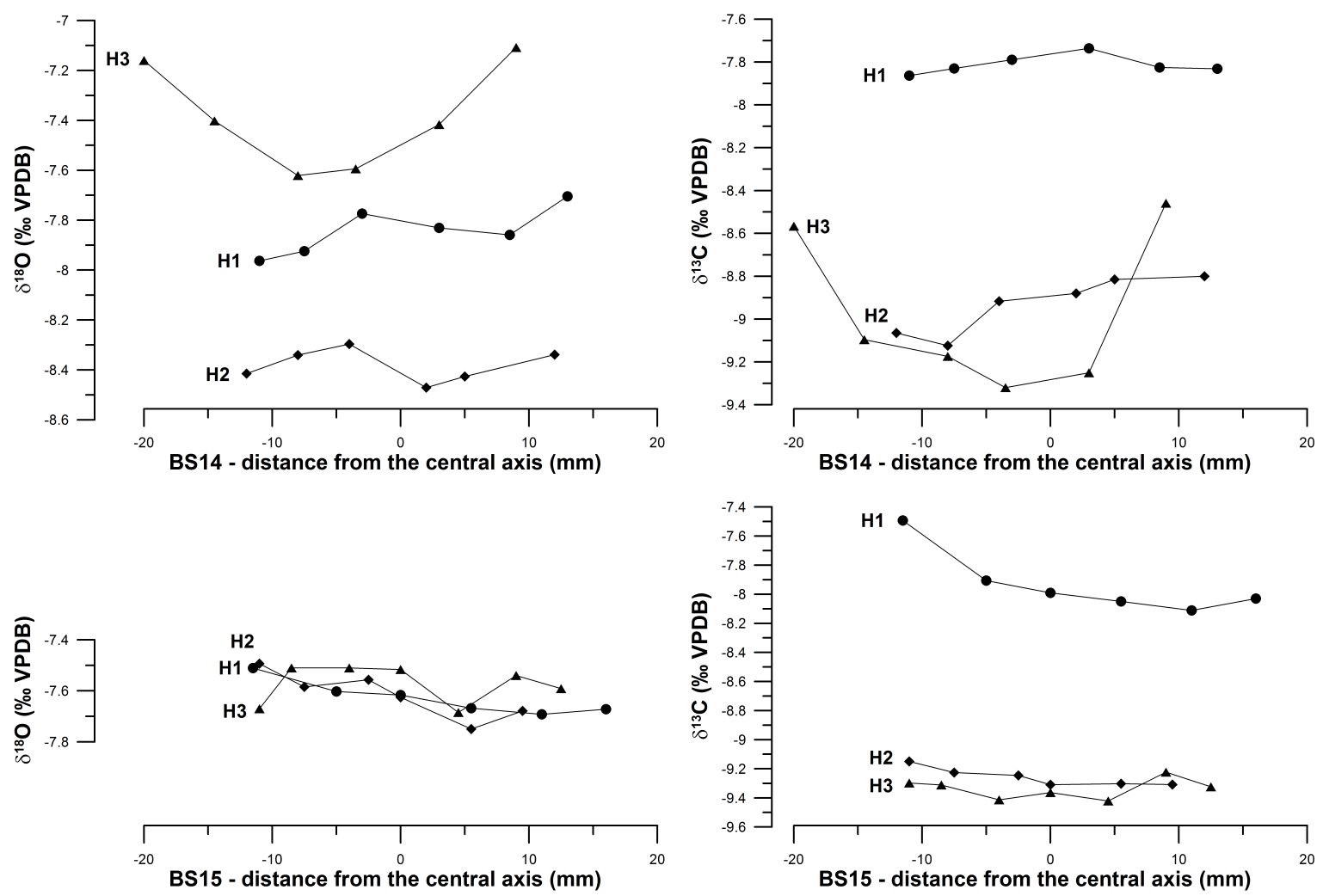

Fig. 5. Hendy test results obtained from three distinct laminae $(\mathrm{H} 1$ to $\mathrm{H} 3)$ on both BS14 and BS15 stalagmites. Stable isotope ratios are plotted according to the horizontal distance from the central axis on a given lamina. $\mathrm{H} 1, \mathrm{H} 2$ and $\mathrm{H} 3$ were sampled, respectively, at 16.5, 31.5, and $59.0 \mathrm{~mm}$ from the top in BS14 and 8.0, 32.5, and $79.0 \mathrm{~mm}$ from the top in BS15.

between $\mathrm{Sr}$ and $\mathrm{Ba}$, and an antiphase trend between $\mathrm{Mg}$ and both $\mathrm{Sr}$ and $\mathrm{Ba}$. The trivalent cation $\mathrm{Y}$, the metals $\mathrm{Cu}$ and $\mathrm{Zn}$, and the electronegative element $\mathrm{P}$ are linked by positive correlations, resulting in common trends. These elements are characterised by strong adsorption behaviour in soils, compared to the solution preference of the divalent cations like $\mathrm{Sr}$ and $\mathrm{Mg}$ (Borsato et al., 2007 and reference therein). No correlation is found between $\mathrm{Mg}$ and $\mathrm{P}$. However, from the observation of their profiles, it is possible to distinguish a trend towards higher values from about $40 \mathrm{~mm}$ from the top (Fig. 6). The Mn signal shows little variability and has a long-term trend towards slightly higher values until $28 \mathrm{~mm}$ from the top, when it starts decreasing again. Considering Th, even if its concentration is just above the instrument detection limit, it shows a higher frequency of spikes in the upper part of the stalagmite starting ca. $48 \mathrm{~mm}$ from its top (Fig. 6).

\section{Petrography}

The polished sections of both stalagmites appear compact (especially stalagmite BS15) and finely laminated in the central portion, while the flanks are more porous and milky. On the polished sections the presence of composite columnar crystals (sensu Frisia et al., 2000) elongated along the growth direction can be distinguished. Two main "palaeo" surfaces marking the temporary interruption of the stalagmite growth have been identified on the polished surface of stalagmite BS14 (at 15 and $25 \mathrm{~mm}$ from the top; $1 \& 3$ in Fig. 3) and one in BS15 (at $18 \mathrm{~mm}$ from the top; surface 1 on Fig. 3). These surfaces have been recognised also in thin section as sharp interruptions of crystal growth

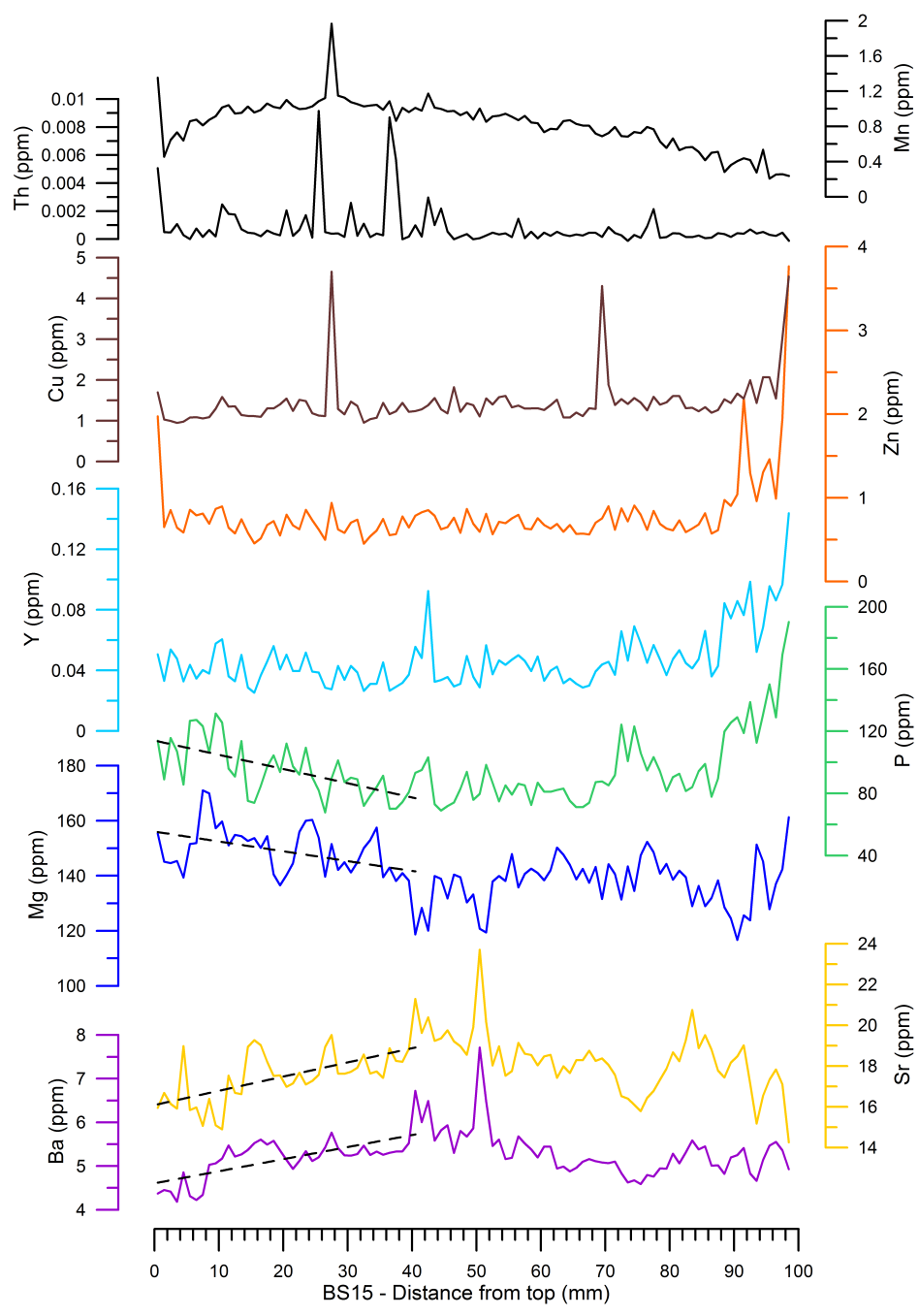

Fig. 6. Trace element concentration in stalagmite BS15 (millimetre average). Black dotted lines indicate the trends towards higher (Mg and P) and lower (Ba and $\mathrm{Sr}$ ) values in the upper $40 \mathrm{~mm}$ of stalagmite BS15. 
Table 2. Pearson correlation coefficients ( $r$ ) between trace element profiles measured on stalagmite BS15. LOD represents the instrument detection limit. Correlation coefficients $(r)$ have been calculated among the data series using the average trace element content millimetre, and corresponds to the same depth scale as the stable isotope data. Statistically significant correlations are indicated in bold.

\begin{tabular}{|c|c|c|c|c|c|c|c|c|c|}
\hline $\begin{array}{c}\text { Trace } \\
\text { elements }\end{array}$ & Mg & $\mathbf{P}$ & Mn & $\mathbf{C u}$ & $\mathbf{Z n}$ & Sr & $\mathbf{Y}$ & $\mathbf{B a}$ & Th \\
\hline LOD & 0.021 & 1.2 & 0.16 & 0.014 & 0.025 & 0.0021 & - & 0.00067 & \\
\hline \multicolumn{10}{|c|}{ CORRELATION COEFFICIENT } \\
\hline $\begin{array}{c}\text { Mg } \\
\text { p value }\end{array}$ & & $\begin{array}{l}0.06 \\
0.54\end{array}$ & $\begin{array}{l}0.29 \\
4 E-3\end{array}$ & $\begin{array}{c}-0.01 \\
0.89\end{array}$ & $\begin{array}{l}0.02 \\
0.81\end{array}$ & $\begin{array}{c}-0.62 \\
1.2 \mathrm{E}-11\end{array}$ & $\begin{array}{l}-0.25 \\
0.01\end{array}$ & $\begin{array}{c}-0.48 \\
5.17 \mathrm{E}-7\end{array}$ & $\begin{array}{l}0.13 \\
0.22\end{array}$ \\
\hline $\begin{array}{c}\mathbf{P} \\
\text { p value }\end{array}$ & $\begin{array}{l}0.06 \\
0.54\end{array}$ & & $\begin{array}{c}-0.46 \\
1.3 \mathrm{E}-6\end{array}$ & $\begin{array}{c}0.41 \\
2.1 \mathrm{E}-5\end{array}$ & $\begin{array}{c}0.74 \\
1.5 \mathrm{E}-18\end{array}$ & $\begin{array}{c}-0.58 \\
3.9 \mathrm{E}-10\end{array}$ & $\begin{array}{c}0.85 \\
3.3 E-28\end{array}$ & $\begin{array}{c}-0.29 \\
3.5 \mathrm{E}-3\end{array}$ & $\begin{array}{c}-0.11 \\
0.22\end{array}$ \\
\hline $\begin{array}{c}\text { Mn } \\
\text { p value }\end{array}$ & $\begin{array}{l}0.29 \\
4 \mathrm{E}-3\end{array}$ & $\begin{array}{c}0.46 \\
1.3 \mathrm{E}-6 \\
\end{array}$ & & $\begin{array}{c}-0.62 \\
0.55\end{array}$ & $\begin{array}{c}-0.36 \\
2.9 E-4\end{array}$ & $\begin{array}{c}0.20 \\
4.9 \mathrm{E}-2\end{array}$ & $\begin{array}{c}-0.57 \\
7.5 E-10\end{array}$ & $\begin{array}{c}0.28 \\
4.6 \mathrm{E}-3\end{array}$ & $\begin{array}{c}0.28 \\
4.8 \mathrm{E}-3 \\
\end{array}$ \\
\hline $\begin{array}{c}\text { Cu } \\
\text { p value }\end{array}$ & $\begin{array}{c}-0.01 \\
0.89 \\
\end{array}$ & $\begin{array}{c}0.41 \\
2.1 \mathrm{E}-5\end{array}$ & $\begin{array}{c}-0.62 \\
0.55 \\
\end{array}$ & & $\begin{array}{c}0.61 \\
2.6 \mathrm{E}-11 \\
\end{array}$ & $\begin{array}{c}-0.11 \\
0.28 \\
\end{array}$ & $\begin{array}{c}0.46 \\
2.2 \mathrm{E}-6 \\
\end{array}$ & $\begin{array}{l}0.02 \\
0.87 \\
\end{array}$ & $\begin{array}{l}0.15 \\
0.14 \\
\end{array}$ \\
\hline $\begin{array}{c}\text { Zn } \\
\text { p value }\end{array}$ & $\begin{array}{l}0.02 \\
0.81 \\
\end{array}$ & $\begin{array}{c}0.74 \\
1.5 \mathrm{E}-18\end{array}$ & $\begin{array}{c}-0.36 \\
2.9 E-4\end{array}$ & $\begin{array}{c}0.61 \\
2.6 \mathrm{E}-11\end{array}$ & & $\begin{array}{c}-0.33 \\
7.8 E-4 \\
\end{array}$ & $\begin{array}{c}0.77 \\
6 E-21\end{array}$ & $\begin{array}{c}-0.13 \\
0.21\end{array}$ & $\begin{array}{c}-0.02 \\
0.88\end{array}$ \\
\hline $\begin{array}{c}\text { Sr } \\
\text { p value }\end{array}$ & $\begin{array}{c}-0.62 \\
1.2 \mathrm{E}-11\end{array}$ & $\begin{array}{c}-0.58 \\
3.9 \mathrm{E}-10\end{array}$ & $\begin{array}{c}0.20 \\
4.9 \mathrm{E}-2\end{array}$ & $\begin{array}{l}0.11 \\
0.28\end{array}$ & $\begin{array}{c}-0.33 \\
7.8 E-4 \\
\end{array}$ & & $\begin{array}{l}-0.29 \\
3 E-3\end{array}$ & $\begin{array}{c}0.82 \\
5.9 \mathrm{E}-25\end{array}$ & $\begin{array}{l}-0.04 \\
0.72\end{array}$ \\
\hline $\begin{array}{c}\mathbf{Y} \\
\mathbf{p} \text { value }\end{array}$ & $\begin{array}{c}-0.25 \\
0.01\end{array}$ & $\begin{array}{c}0.85 \\
3.3 \mathrm{E}-28\end{array}$ & $\begin{array}{c}-0.57 \\
7.5 \mathrm{E}-10\end{array}$ & $\begin{array}{c}0.46 \\
2.2 \mathrm{E}-6\end{array}$ & $\begin{array}{c}0.77 \\
6 E-21\end{array}$ & $\begin{array}{l}-0.29 \\
3 E-3\end{array}$ & & $\begin{array}{c}-0.06 \\
0.57\end{array}$ & $\begin{array}{c}-0.09 \\
0.37\end{array}$ \\
\hline $\begin{array}{c}\mathrm{Ba} \\
\mathrm{p} \text { value }\end{array}$ & $\begin{array}{c}-0.48 \\
5.17 \mathrm{E}-7\end{array}$ & $\begin{array}{c}-0.29 \\
3.5 \mathrm{E}-3\end{array}$ & $\begin{array}{c}0.28 \\
4.6 \mathrm{E}-3\end{array}$ & $\begin{array}{l}0.02 \\
0.87\end{array}$ & $\begin{array}{c}-0.13 \\
0.21\end{array}$ & $\begin{array}{c}0.82 \\
5.9 \mathrm{E}-25\end{array}$ & $\begin{array}{l}-0.06 \\
0.57\end{array}$ & & $\begin{array}{c}-0.01 \\
0.95\end{array}$ \\
\hline $\begin{array}{c}\delta^{13} \mathbf{C} \\
p \text { value }\end{array}$ & $\begin{array}{c}0.72 \\
9.8 \mathrm{E}-17\end{array}$ & $\begin{array}{l}0.14 \\
0.16\end{array}$ & $\begin{array}{l}0.31 \\
2 \mathrm{E}-3\end{array}$ & $\begin{array}{c}-0.08 \\
0.44\end{array}$ & $\begin{array}{c}-0.08 \\
0.41\end{array}$ & $\begin{array}{c}-0.55 \\
3.3 E-9\end{array}$ & $\begin{array}{c}-0.20 \\
0.03\end{array}$ & $\begin{array}{c}-0.44 \\
4.5 \mathrm{E}-6\end{array}$ & $\begin{array}{l}0.02 \\
0.86\end{array}$ \\
\hline
\end{tabular}

marked by visible crystal terminations associated with brown, dense surfaces coating crystal tips, especially in stalagmite BS14. Several other similar surfaces, presenting a sharp contact with the underlying laminae, are visible under the microscope only and possibly represent short-term hiatuses (e.g., a surface observed at $18 \mathrm{~mm}$ from the top in BS14 presents evidence of crystal-growth competition, demonstrating the presence of a growth interruption; surface 2 in Fig. 3).

In thin section, the textures observed on the polished stalagmite surfaces result mainly in large, columnar, microcrystalline, composite crystals, with the exception of dendritic calcite in a few areas. These composite crystals consist of aggregates stacked with their $c$-axes oriented parallel to the vertical growth axis of the whole stalagmite, which may show mismatched stacking relative to the vertical growth direction in the upper portion of the stalagmite. The crystallites forming these composite crystals show optical continuity under polarised light. Relatively irregular vertical limits, which alternate with interfingered portions, characterise the composite crystals. This feature suggests subtle transitions to zones of higher proportion of impurities favouring the formation of crystal defects, resulting in high, intracrystalline microporosity (Frisia, 2015; Fig. 7). Brownish lamination related to periodic input of detrital/colloidal particulates is visible in both stalagmites (cf. Frisia et al., 2000).

The following detailed classification of fabrics from our samples is a subdivision of the columnar microcrystalline fabric, based on the observed porosity and composite crystal boundaries, from which crystallite size at the laminae scale was inferred (Fig. 8):

1) Highly compact and translucent laminae consisting of welded crystallites, suggesting negligible presence of particulate and/or foreign
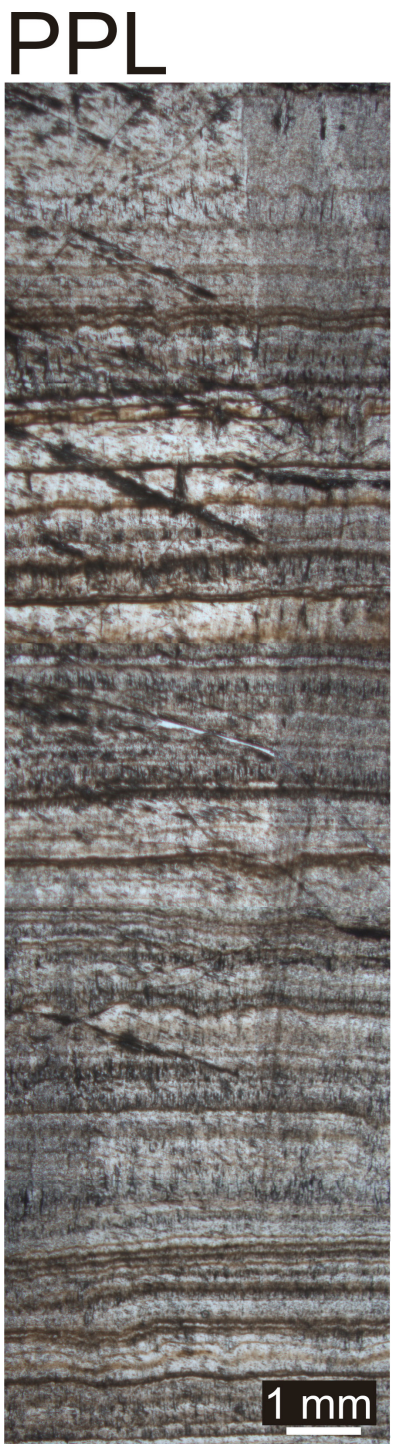
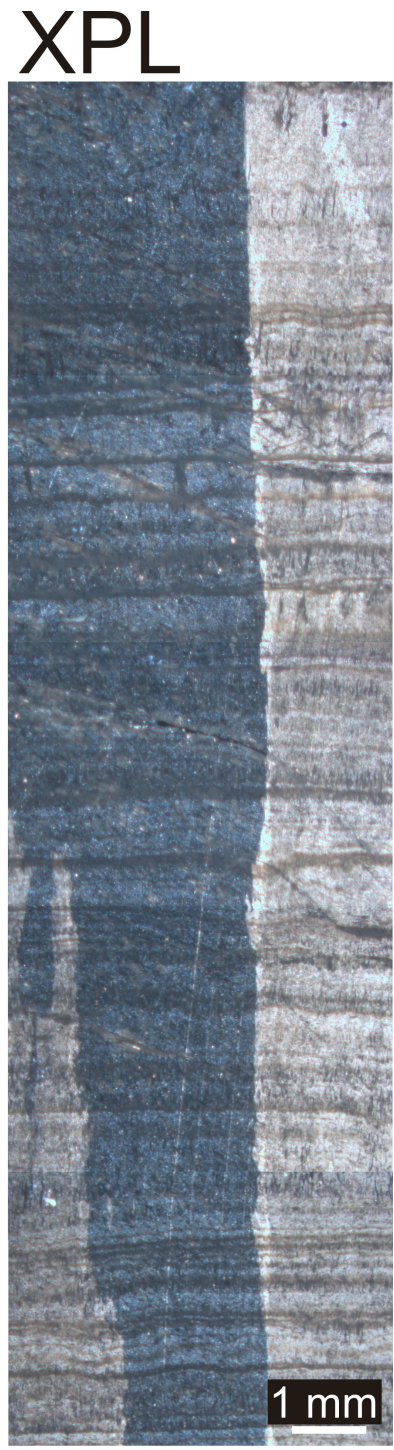

Fig. 7. Vertical log of a portion of the thin section of stalagmite BS15 showing the composite columnar crystals characterised by the presence of relatively straight and irregular/interfingered boundaries. Different calcite crystallites arrangements are visible at the scale of lamination inside the composite crystals. 
ions that would create lattice deformation or occlude growth sites. This fabric subtype has here been classified as compact columnar microcrystalline calcite (Ccm, Fig. 8a). Laminae formed by this fabric are bound by "wavy" brownish surfaces, corresponding to flattened calcite crystal terminations and to cavities in the below compact carbonate lamina (Supplemental Fig. S1).

2) Some groups of laminae differentiate from the previous fabric $(\mathrm{Ccm})$ by the occurrence of linear intercrystalline porosity. The boundaries between the composite crystals are irregular, suggesting that foreign ions or particulates occluded growth sites. Overall, the laminae appear milkier than in $\mathrm{Ccm}$, and, under the optical microscope, show the presence of colloid-rich brown laminae with similar features as in $\mathrm{Ccm}$. This fabric subtype has been classified as open columnar microcrystalline calcite (Ocm, Fig. 8b).

3) Another fabric, observed only in the younger portion of stalagmite BS14, is characterised by elongated aggregates of crystallites (Fig. 8c). The composite crystal boundaries range from straight to interfingered. This is possibly related to a different content in particulate. This fabric is very similar to the elongated columnar calcite (sensu Frisia, 2015), which occurs under relatively high (>0.3) Mg/Ca ratio of parent drip water associated with relatively fast dripping; when this fabric is associated with micrite and lateral overgrowth, diagenesis may have occurred (Frisia, 2015). However, the elongated appearance in this case is given by the succession of vertically oriented

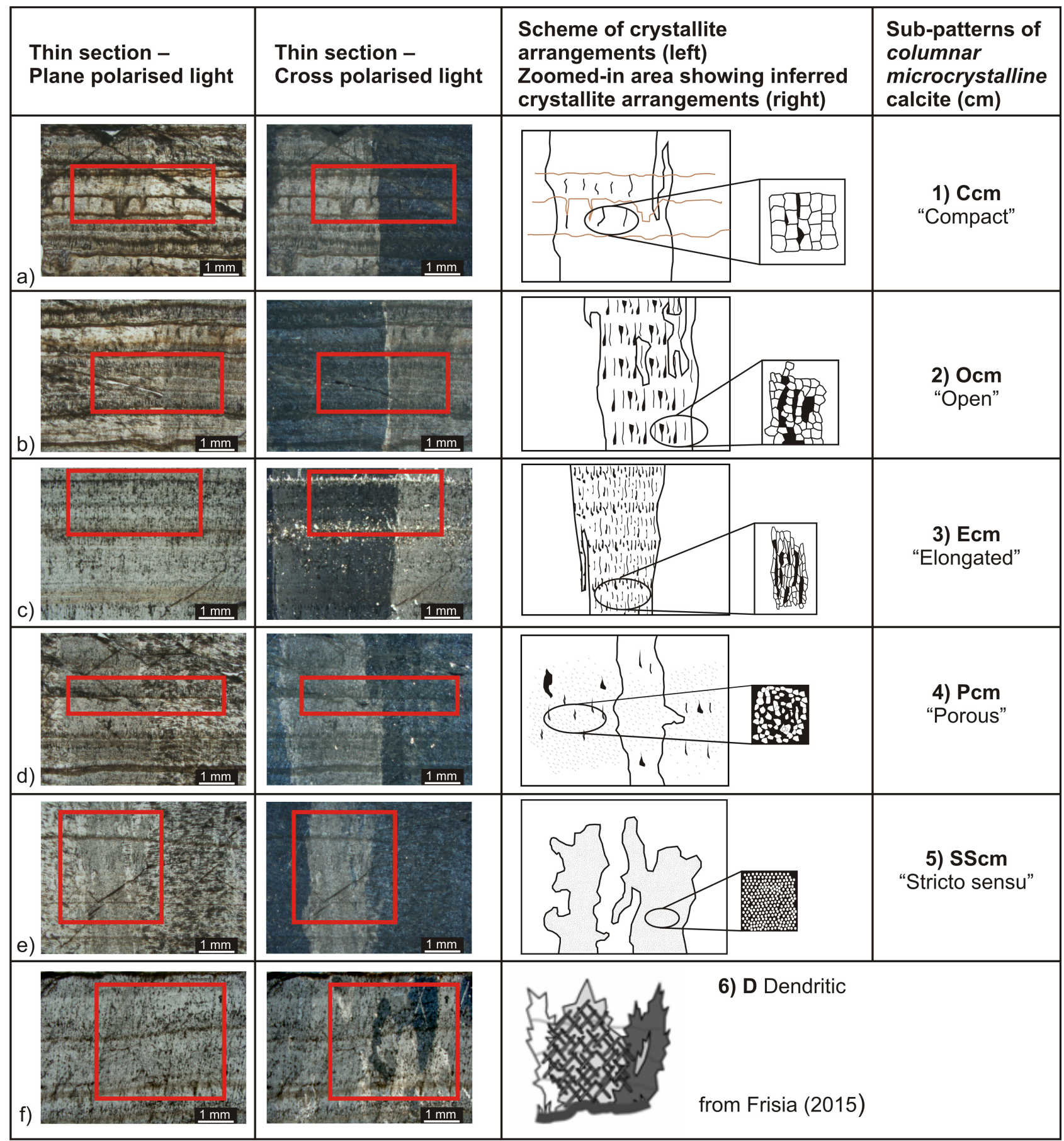

Fig. 8. Fabric subdivision and classification (plane and cross polarised light) modified from Frisia (2015). The white scale on the picture represents $1 \mathrm{~mm}$. The red frames surround the targeted fabric for each sub-type, as described in the columns on the right. 
pores, which, in turn, are characterised by irregular boundaries preventing the identification of size and geometry of single crystallites. This suggests the presence of foreign particles favouring the formation of crystal defects, which are reflected in the observed irregular shapes (Frisia, 2015). Thus, this fabric has been referred to as elongated microcrystalline calcite $\mathbf{E c m}$; Fig. 8c).

4) Some sets of laminae consist of microcrystalline fabric, crossed by narrow, vertically oriented linear porosities and composite crystals with irregular boundaries similar to those illustrated by Frisia et al. (2000). Thus, the fabric has been classified as porous microcrystalline calcite $(\mathbf{P c m}$; Fig. 8d). It differentiates from Ocm by the presence of a less regular intercrystalline linear porosity and a higher intracrystalline porosity inferred from the more irregular boundaries of the composite crystals. As for Ocm, some intervals attributed to the porous microcrystalline subtype contain brownish laminae, testifying the input of colloidal particulates, which, in this specific fabric, must have efficiently occluded growth sites.

5) The last columnar microcrystalline subtype identified in the Bosnian stalagmites is most common in the younger portion of BS15, and rare in BS14. The composite crystals show irregular boundaries more pronounced than in Pcm, but absent, or rare, elongated porosities. This fabric has thus been classified as stricto sensu microcrystalline calcite (SScm; Fig. 8e).

6) The only non-columnar fabric identified in the stalagmites is dendritic (D), as described in Frisia et al. (2000), Couchoud (2006), Banks et al. (2010) and Frisia (2015). It can be observed on the flanks of both stalagmites and in the upper part of BS14 (Fig. 8f). The dendritic fabric is characterised by crystals that are not elongated along the growth axis of the stalagmites, and the composite crystals form branching assemblages, with a $60^{\circ}$ angle.

The brownish lamination cited above, which is believed to be related to periodic input of colloidal/ detrital particulate, has not been considered for this classification, but has been treated separately, assigning the value 0 to the pattern lacking the brownish lamination and the value 1 to the laminated one. This feature and the fabric subtypes are then represented as a function of distance from the stalagmite top, in profiles that can be compared with the geochemical data to discuss hydrological changes (Fig. 4).

\section{Statistical approach used to couple petrography and geochemical signals}

According to the statistical approach described in the methods section, the classified petrography groups present a different and specific $\delta^{13} \mathrm{C}$ and $\delta^{18} \mathrm{O}$ composition (Kruskal-Wallis test; Table 3). In particular, the IsoFab plot highlighted progressively higher isotopic values from $\mathrm{Ccm}$ to $\mathrm{D}$ (Fig. 9). The multiple tests between the groups display a
Table 3. Results from the Kruskal-Wallis test to determine the significance of covariation between petrography and stable isotopes in stalagmites BS14 and BS15. The null hypothesis is the presence of similar isotopic composition for each of the considered petrography groups. $\mathrm{H}$ is the calculated test statistic and Hcrit. is the critical value of $\mathrm{H}$ from the Kruskal-Wallis table beyond which the null hypothesis must be rejected at the $95 \%$.

\begin{tabular}{|c|c|c|c|c|}
\hline $\begin{array}{c}\text { Kruskal-Wallis } \\
\text { test }\end{array}$ & $\mathbf{H}$ & Hcrit. (0.05) & $\begin{array}{r}\text { Petrogr } \\
\text { groups S } \\
\text { siz }\end{array}$ & aphy \\
\hline $\begin{array}{l}\text { BS14 } \\
\delta^{18} \mathrm{O} \\
\delta^{13} \mathrm{C}\end{array}$ & $\begin{array}{l}23.20 \\
51.69\end{array}$ & $\begin{array}{l}11.07 \\
11.07\end{array}$ & $\begin{array}{l}\text { 1) } \mathrm{Ccm} \\
\text { 2) } \mathrm{Ocm} \\
\text { 3) } \mathrm{Ecm} \\
\text { 4) } \mathrm{Pcm} \\
\text { 5) } \mathrm{SScm} \\
\text { 6) } \mathrm{D}\end{array}$ & $\begin{array}{l}\mathrm{n}=16 \\
\mathrm{n}=11 \\
\mathrm{n}=17 \\
\mathrm{n}=20 \\
\mathrm{n}=5 \\
\mathrm{n}=4\end{array}$ \\
\hline $\begin{array}{c}\text { BS15 } \\
\delta^{18} \mathrm{O} \\
\\
\delta^{13} \mathrm{C}\end{array}$ & $\begin{array}{l}10.01 \\
43.84\end{array}$ & $\begin{array}{l}9.49 \\
9.49\end{array}$ & $\begin{array}{l}\text { 1) } \mathrm{Ccm} \\
\text { 2) } \mathrm{Ocm} \\
\text { 4) } \mathrm{Ecm} \\
\text { 5) } \mathrm{SScm}\end{array}$ & $\begin{array}{l}\mathrm{n}=4 \\
\mathrm{n}=20 \\
\mathrm{n}=64 \\
\mathrm{n}=12\end{array}$ \\
\hline
\end{tabular}

statistically different $\delta^{13} \mathrm{C}$ composition of petrography classes and a less marked $\delta^{18} \mathrm{O}$ signature (Table 4 and Fig. 9). According to discriminant analyses, $47 \%$ (stalagmite BS14) and 55\% (stalagmite BS15) can be well classified into their petrography group based on their stable isotope composition: the graphic representation displays the presence of distinct isotopic composition for each petrography group (Fig. 10). The discriminant analyses performed considering 4 variables $\left(\delta^{13} \mathrm{C}, \delta^{18} \mathrm{O}, \mathrm{Mg}\right.$, and $\left.\mathrm{Sr}\right)$ on stalagmite BS15 petrography, results in a good distinction of the different petrography groups $(67.7 \%$ of samples well classified; Fig. 10).

\section{DISCUSSION}

\section{Trace element variations in stalagmite BS15}

The trace element composition of speleothems is related largely to hydrochemical processes in the unsaturated zone overlying the cave (i.e., Roberts et al., 1998; Huang \& Fairchild, 2001; Fairchild et al, 2006; Borsato et al., 2007; Fairchild \& Treble, 2009). Variations in calcite trace element concentration thus provide information on water-rock interaction, which relates to climate (Fairchild \& Treble, 2009). In addition, the type and density of vegetation cover, which can be either related to climate or human activities, can influence trace element variation (Borsato et al., 2007). The understanding of the mechanisms responsible for their fluctuations in a given cave site is crucial for a correct interpretation of the trace element environmental significance.

In the studied stalagmite, a negative correlation appears between $\mathrm{Sr}$ and $\mathrm{Mg}$ at a millimetre scale (Fig. 11; Table 2). This opposed behaviour, also observed by Roberts et al. (1998) and Treble et al. (2013) would exclude the occurrence of prolonged and intense dry periods, causing relevant phases of prior calcite precipitation (PCP), at least at a decadal time scale. This phenomenon, in fact, would be reflected in a positive correlation of both trace elements (Fairchild $\&$ Treble, 2009). Mucci \& Morse (1990) demonstrated that temperature influences variations in $\mathrm{Mg}$ concentration. However, $\mathrm{Mg}$ concentration in parent drip water is also closely related to water residence 


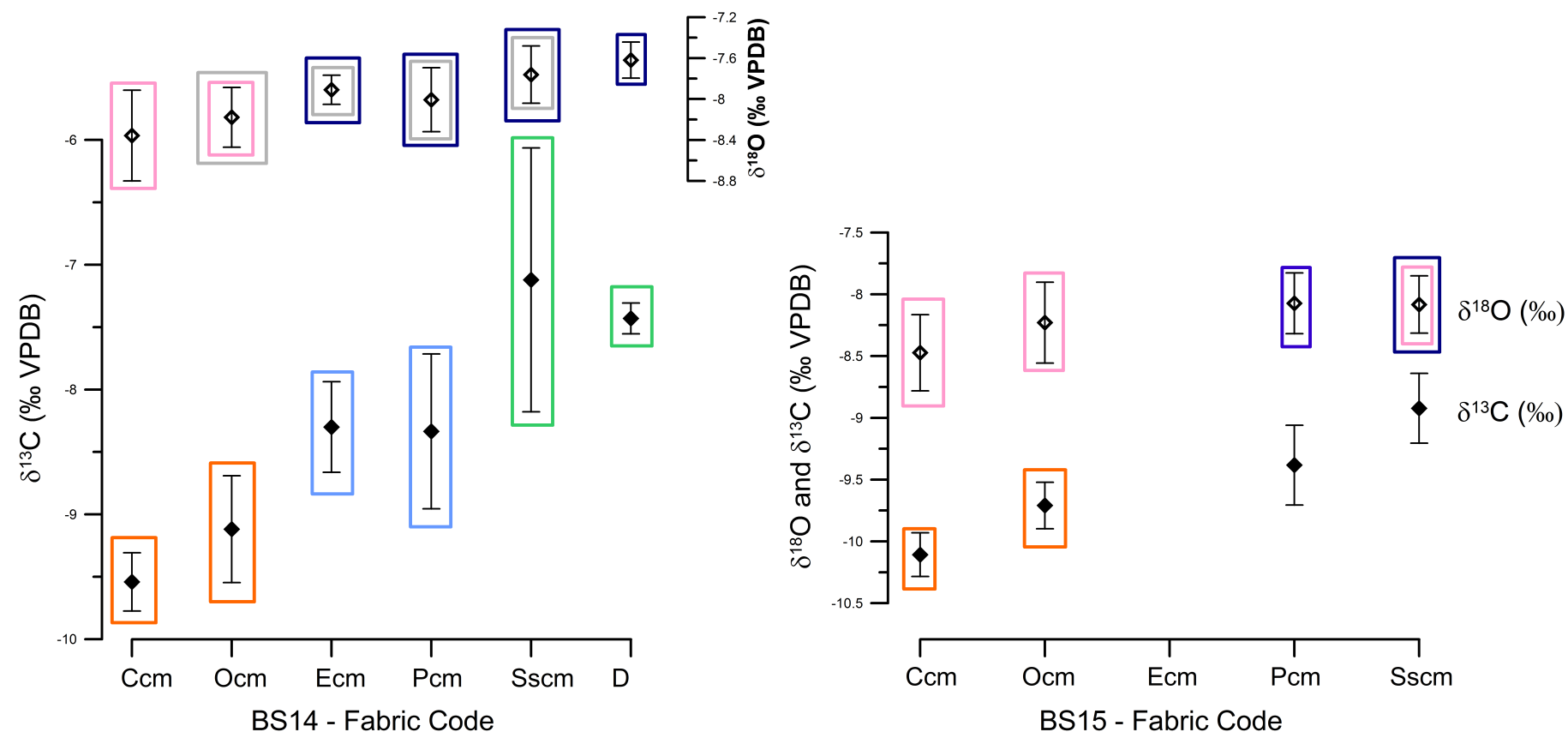

Fig. 9. Isotope-fabric plots for BS14 and BS15 stalagmites. For each fabric type, average $\delta^{13} \mathrm{C}$ and $\delta^{18} \mathrm{O}$ values are plotted with their standard deviation. Isotope compositions that cannot be considered statistically different (significance level 0.05 ; Table 4 ) are indicated with rectangles of the same colour.

Table 4. Bonferroni test results between petrography groups in stalagmites BS14 and BS15 for $\delta^{18} \mathrm{O}$ and $\delta^{13} \mathrm{C}$ ratios. Probability value is indicated for both isotopic ratios. Bold italic values indicate significantly different groups in terms of $\delta^{18} \mathrm{O}$ and/or $\delta^{13} \mathrm{C}$ composition ( 0.05 significance level).

\begin{tabular}{|c|c|c|c|c|c|c|}
\hline BS14 & 1) $\mathrm{Ccm}$ & 2) $0 \mathrm{~cm}$ & 3) $\mathrm{Ecm}$ & 4) $\mathrm{Pcm}$ & 5) SScm & 6) $D$ \\
\hline 1) $\mathrm{Ccm}$ & & $\begin{array}{c}\delta^{18} \mathrm{O}: 1 \\
\delta^{13} \mathrm{C}: 0.514\end{array}$ & $\begin{array}{c}\mathrm{\delta}^{18} \mathrm{O}: \boldsymbol{0 . 0 0 1} \\
\delta^{13} \mathrm{C}: \mathbf{1 . 3 E - 8}\end{array}$ & $\begin{array}{c}\delta^{18} \mathrm{O}: 0.018 \\
\delta^{13} \mathrm{C}: \mathbf{9 . 7 E - 1 0}\end{array}$ & $\begin{array}{c}\delta^{18} \mathrm{O}: \boldsymbol{0 . 0 0 5} \\
\mathrm{\delta}^{13} \mathrm{C}: \mathbf{8 . 5 E - 1 3}\end{array}$ & $\begin{array}{l}\delta^{18} \mathrm{O}: \boldsymbol{0 . 0 0 1} \\
\delta^{13} \mathrm{C}: \mathbf{2 . 3 E - 9}\end{array}$ \\
\hline 2) $0 \mathrm{~cm}$ & $\begin{array}{c}\delta^{18} \mathrm{O}: 1 \\
\delta^{13} \mathrm{C}: 0.514 \\
\end{array}$ & & $\begin{array}{l}\delta^{18} \mathrm{O}: 0.395 \\
\delta^{13} \mathrm{C}: \boldsymbol{0 . 0 0 1}\end{array}$ & $\begin{array}{c}\delta^{18} \mathrm{O}: 1 \\
\delta^{13} \mathrm{C}: \boldsymbol{0 . 0 0 1} \\
\end{array}$ & $\begin{array}{c}\delta^{18} \mathrm{O}: 0.213 \\
\delta^{13} \mathrm{C}: \mathbf{4 E}-\mathbf{9}\end{array}$ & $\begin{array}{l}\delta^{18} \mathrm{O}: \boldsymbol{0 . 0 4 0} \\
\delta^{13} \mathrm{C}: \mathbf{3 . 2 E - 6}\end{array}$ \\
\hline 3) $\mathrm{Ecm}$ & $\begin{array}{c}\delta^{18} \mathrm{O}: \boldsymbol{0 . 0 1} \\
\delta^{13} \mathrm{C}: \mathbf{1 . 3 E - 8}\end{array}$ & $\begin{array}{l}\delta^{18} \mathrm{O}: 0.395 \\
\delta^{13} \mathrm{C}: \boldsymbol{0 . 0 0 1}\end{array}$ & & $\begin{array}{l}\delta^{18} \mathrm{O}: 1 \\
\delta^{13} \mathrm{C}: 1\end{array}$ & $\begin{array}{c}\delta^{18} \mathrm{O}: 1 \\
\delta^{13} \mathrm{C}: \mathbf{2 . 4 E}-\mathbf{4}\end{array}$ & $\begin{array}{c}\delta^{18} \mathrm{O}: 1 \\
\delta^{13} \mathrm{C}: \boldsymbol{0 . 0 3 9} \\
\end{array}$ \\
\hline 4) $P c m$ & $\begin{array}{c}\delta^{18} \mathrm{O}: \mathbf{0 . 0 1 8} \\
\delta^{13} \mathrm{C}: \mathbf{9 . 7 E - 1 0}\end{array}$ & $\begin{array}{c}\delta^{18} \mathrm{O}: 1 \\
\mathrm{\delta}^{13} \mathrm{C}: \boldsymbol{0 . 0 0 1}\end{array}$ & $\begin{array}{l}\delta^{18} \mathrm{O}: 1 \\
\delta^{13} \mathrm{C}: 1\end{array}$ & & $\begin{array}{c}\delta^{18} \mathrm{O}: 1 \\
\delta^{13} \mathrm{C}: \mathbf{1} \cdot \mathbf{1 E - 4}\end{array}$ & $\begin{array}{l}\delta^{18} \mathrm{O}: 0.374 \\
\delta^{13} \mathrm{C}: \boldsymbol{0 . 0 2 4}\end{array}$ \\
\hline 5) $\mathrm{SScm}$ & $\begin{array}{c}\delta^{18} \mathrm{O}: \boldsymbol{0 . 0 0 5} \\
\delta^{13} \mathrm{C}: \mathbf{8 . 5 E - 1 3}\end{array}$ & $\begin{array}{c}\delta^{18} \mathrm{O}: 0.213 \\
\delta^{13} \mathrm{C}: \mathbf{4 E - 9}\end{array}$ & $\begin{array}{c}\delta^{18} \mathrm{O}: 1 \\
\delta^{13} \mathrm{C}: \mathbf{2 . 4 E}-\mathbf{4}\end{array}$ & $\begin{array}{c}\delta^{18} \mathrm{O}: 1 \\
\delta^{13} \mathrm{C}: \mathbf{1 . 1 E}-\mathbf{4}\end{array}$ & & $\begin{array}{l}\delta^{18} \mathrm{O}: 1 \\
\delta^{13} \mathrm{C}: 1\end{array}$ \\
\hline 6) D & $\begin{array}{c}\delta^{18} \mathrm{O}: \boldsymbol{0 . 0 1} \\
\delta^{13} \mathrm{C}: \mathbf{2 . 3 E}-\mathbf{9}\end{array}$ & $\begin{array}{c}\delta^{18} \mathrm{O}: \boldsymbol{0 . 0 4 0} \\
\mathrm{\delta}^{13} \mathrm{C}: \mathbf{3 . 2 E - 6}\end{array}$ & $\begin{array}{c}\delta^{18} \mathrm{O}: 1 \\
\delta^{13} \mathrm{C}: \boldsymbol{0 . 0 3 9}\end{array}$ & $\begin{array}{l}\delta^{18} \mathrm{O}: 0.374 \\
\delta^{13} \mathrm{C}: \boldsymbol{0 . 0 2 4}\end{array}$ & $\begin{array}{l}\delta^{18} \mathrm{O}: 1 \\
\delta^{13} \mathrm{C}: 1\end{array}$ & \\
\hline BS15 & 1) $\mathrm{Ccm}$ & 2) $0 \mathrm{~cm}$ & & 4) Pcm & 5) SScm & \\
\hline 1) $\mathrm{Ccm}$ & & $\begin{array}{l}\mathrm{S}^{18} \mathrm{O}: 0.703 \\
\delta^{13} \mathrm{C}: 0.076\end{array}$ & & $\begin{array}{l}\delta^{18} \mathrm{O}: \boldsymbol{0 . 0 1 8} \\
\delta^{13} \mathrm{C}: \mathbf{3 . 6 E - 5}\end{array}$ & $\begin{array}{c}\delta^{18} \mathrm{O}: 0.065 \\
\delta^{13} \mathrm{C}: \mathbf{2 . 3 E - 9}\end{array}$ & \\
\hline 2) $0 \mathrm{~cm}$ & $\begin{array}{l}\delta^{18} \mathrm{O}: 0.703 \\
\delta^{13} \mathrm{C}: 0.076\end{array}$ & & & $\begin{array}{c}\delta^{18} \mathrm{O}: \boldsymbol{0 . 0 4 4} \\
\delta^{13} \mathrm{C}: \mathbf{3 . 3 E}-\mathbf{4}\end{array}$ & $\begin{array}{c}\delta^{18} \mathrm{O}: 0.517 \\
\delta^{13} \mathrm{C}: \mathbf{6 . 9 E - 1 0}\end{array}$ & \\
\hline 4) $P c m$ & $\begin{array}{l}\delta^{18} \mathrm{O}: \boldsymbol{0 . 0 1 8} \\
\mathrm{S}^{13} \mathrm{C}: \mathbf{3 . 6 E - 5}\end{array}$ & $\begin{array}{c}\delta^{18} \mathrm{O}: \boldsymbol{0 . 0 4 4} \\
\delta^{13} \mathrm{C}: \mathbf{3 . 3 E}-4\end{array}$ & & & $\begin{array}{c}\delta^{18} \mathrm{O}: 1 \\
\delta^{13} \mathrm{C}: \mathbf{1 . 8 E - 5}\end{array}$ & \\
\hline 5) SScm & $\begin{array}{c}\delta^{18} \mathrm{O}: 0.065 \\
\delta^{13} \mathrm{C}: \mathbf{2 . 3 E - 9}\end{array}$ & $\begin{array}{c}\delta^{18} \mathrm{O}: 0.517 \\
\delta^{13} \mathrm{C}: \mathbf{6 . 9 E - 1 0}\end{array}$ & & $\begin{array}{c}\delta^{18} \mathrm{O}: 1 \\
\delta^{13} \mathrm{C}: \mathbf{1 . 8 E - 5}\end{array}$ & & \\
\hline
\end{tabular}

time: drier conditions induce longer residence times and allow for selective leaching of $\mathrm{Mg}$ from soil or host rock, when the host rock is dolomite or Mg-bearing carbonate/metamorphic/igneous rock (Plummer, 1977; Fairchild et al., 2000). Sr can be related to calcite precipitation rate, where higher concentrations would indicate faster speleothem growth (Huang \& Fairchild, 2001). Thus, the antiphased variations of both elements in the studied stalagmite may be related to differential weathering of limestone and dolomite/Mg-bearing carbonate bedrock as a result of groundwater residence time (e.g., Huang et al., 2001). Their trends could thus be explained as the result of hydrological processes: the alternation of relatively dry periods characterised by longer groundwater residence time and wetter periods, with a faster aquifer transmission and, possibly, higher growth rates (cf. Treble et al., 2013).
$\mathrm{P}$ concentration in speleothems is commonly interpreted as being related to vegetation die-back or microbial mats (Huang et al., 2001; Treble et al., 2005; Borsato et al., 2007; Fairchild and Treble, 2009). The mobility of $\mathrm{P}$ in soils is higher at a $\mathrm{pH}$ between 4 and 6 (Giesler et al., 2005), conditions that usually occur in summer (Sartori et al., 2005). However, P is commonly re-adsorbed by the loweralkaline soil layer, maintaining its mobility only in presence of extremely rapid infiltration, as witnessed by its positive correlation with $\mathrm{Y}, \mathrm{Zn}$ and $\mathrm{Cu}$ (e.g., Borsato et al., 2007). Given that plants consume $\mathrm{P}$ during their growing period, and that autumn is one of the wettest periods, its mobilisation should mainly occur during this season, when vegetation becomes dormant in temperate climates (Frisia, 2015 and reference therein). Autumnal organic matter flushing 
BS14 - canonical discriminant function based on $\delta^{18} \mathrm{O}$ and $\delta^{13} \mathrm{C}$ variables

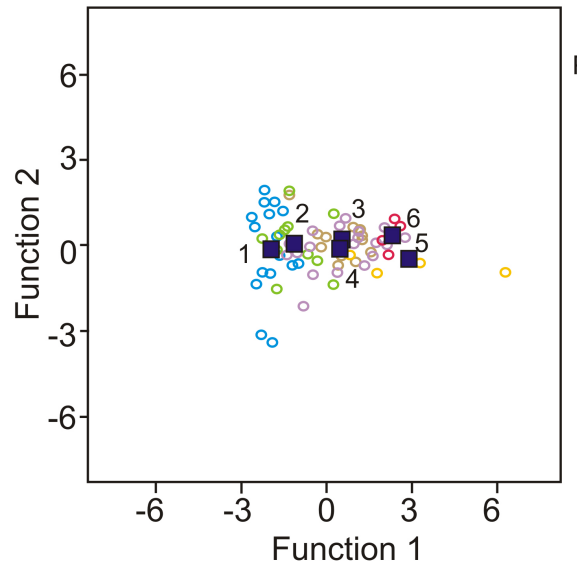

BS15 - canonical discriminant function based on $\delta^{18} \mathrm{O}$ and $\delta^{13} \mathrm{C}, \mathrm{Mg}$ and $\mathrm{Sr}$ variables

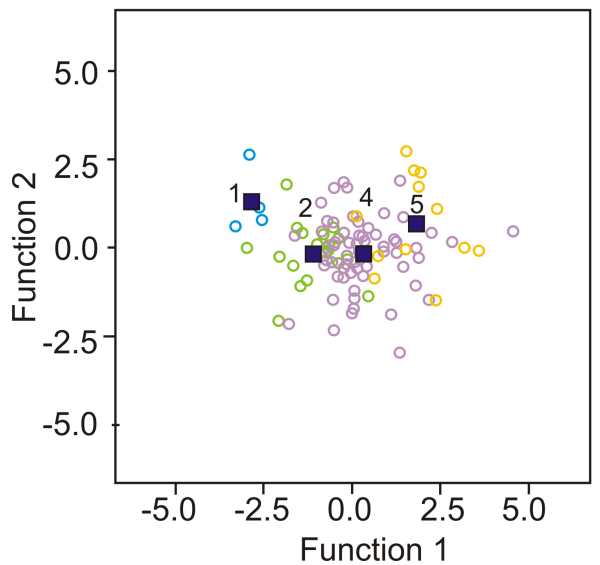

BS15 - canonical discriminant function based on $\delta^{18} \mathrm{O}$ and $\delta^{13} \mathrm{C}$ variables

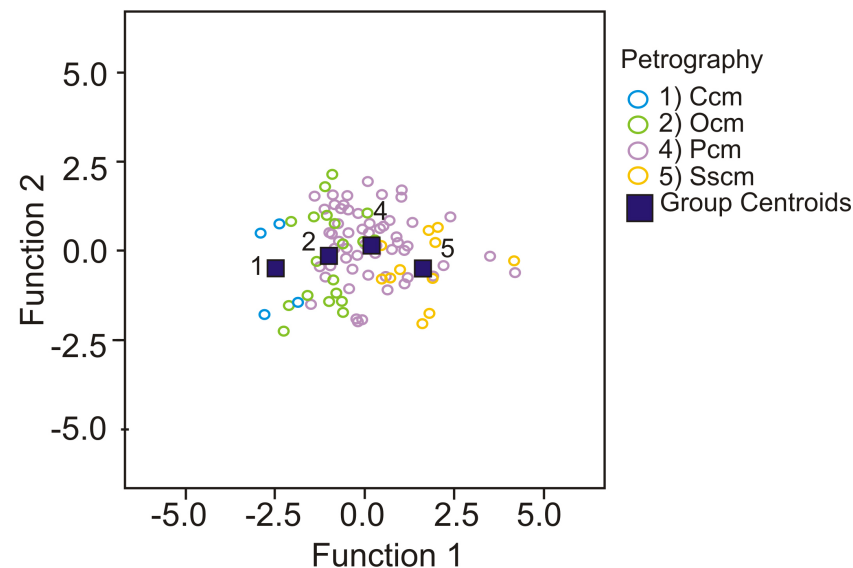

Fig. 10. Discriminant analyses charts using 2 parameters $\left(\delta^{13} \mathrm{C}\right.$ and $\left.\delta^{18} \mathrm{O}\right)$ to define the petrography classes for BS14 and BS15 (top), and 4 parameters $(\delta 13 \mathrm{C}, \delta 18 \mathrm{O}, \mathrm{Mg}$, and $\mathrm{Sr}$ ) to define petrography classes in BS15 (bottom).

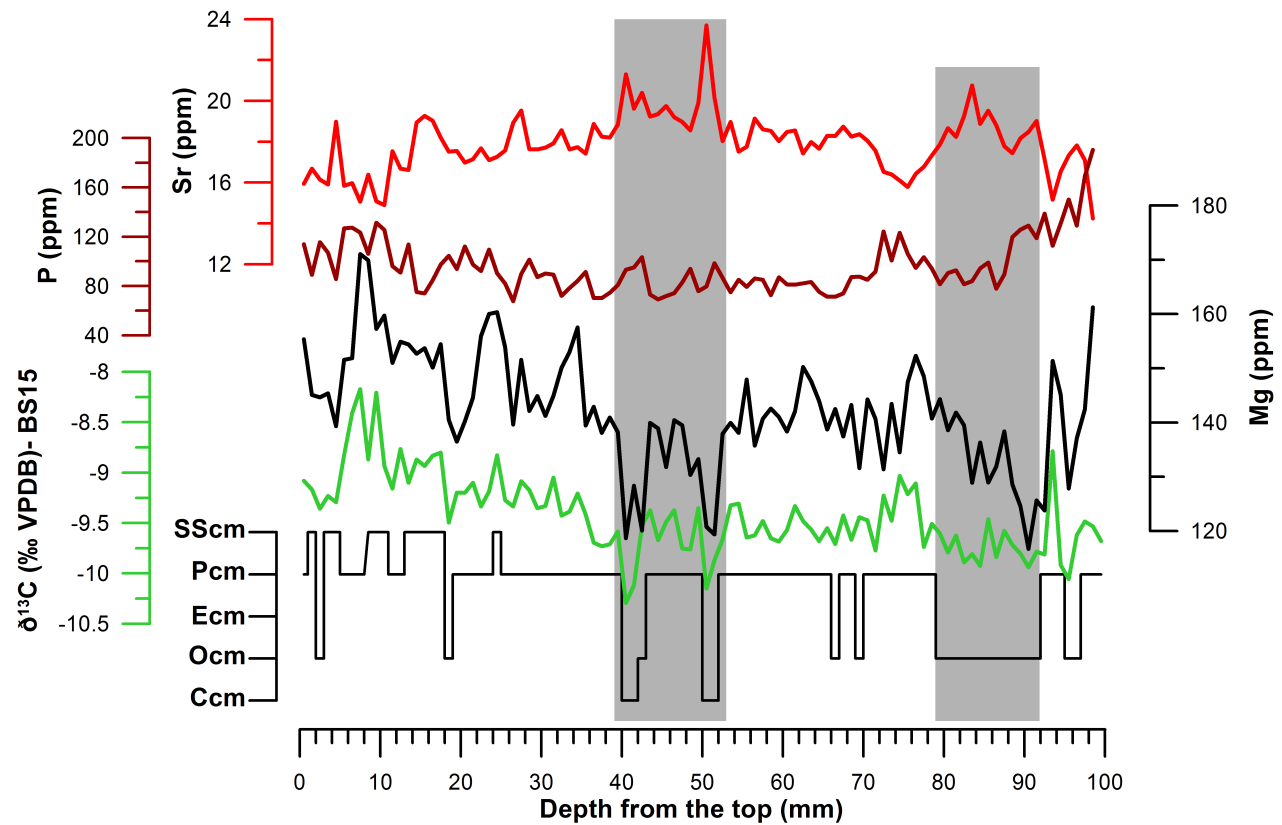

Fig. 11. Trace elements (Sr, P, Mg: average calculated every millimetre corresponding to the stable isotope profile), $\delta^{13} \mathrm{C}$, and petrography variations in stalagmite BS15. The grey shading highlights the portions corresponding to peaks in $\mathrm{Sr}$ content, lower $\delta^{13} \mathrm{C}$ values, and lower $\mathrm{Mg}$ content.

often results in a brownish coating at stalagmite tips that can act as a growth inhibitor. The hypothesis of autumnal flushing of $\mathrm{P}$ is further supported by its negative correlation with $\mathrm{Sr}(r=-0.58 ; p<0.001$, Table 2), since $\mathrm{Sr}$ is usually incorporated into stalagmite calcite lattice during period of high growth rate (Huang \& Fairchild, 2001).

More frequent Th peaks are finally observed in the upper $40 \mathrm{~mm}$ of stalagmite BS15. Considering that Th has an extremely low solubility in water, its increase 
in this portion of the stalagmite is likely related to a higher detritus load in the parent drip water.

\section{Stable isotope variability in stalagmites BS14 and BS15 and comparison with trace element profiles in stalagmite BS15}

In stalagmite $\mathrm{BS} 15$, the $\delta^{18} \mathrm{O}$ and $\delta^{13} \mathrm{C}$ profiles present similar trends at the centennial scale more visible in its upper half (Fig. 4). Considering the $\mathrm{Mg}$-Sr negative correlation described earlier, the occurrence of prior calcite precipitation (PCP) is excluded as a possible factor for such a long $\delta^{13} \mathrm{C}$ and $\delta^{18} \mathrm{O}$ covariation. In stalagmite BS14, covariation of the two stable isotope ratios is observed (Fig. 4). According to Hendy (1971), covariation along the growth axis is one of the indicators of calcite deposition under disequilibrium conditions. However, several other authors recognised the role played by climate fluctuations in causing covariation of $\delta^{13} \mathrm{C}$ and $\delta^{18} \mathrm{O}$ (i.e., vegetation changes associated with climate changes; Cerling, 1984; Dorale et al., 1992; 1998). Considering the temperature-dependent fractionation factor (between $\sim 0.37$ and $0.17 \% \circ /{ }^{\circ} \mathrm{C}$ ) of the stable isotope composition of precipitation in the Balkans (Vreča et al., 2006), the $\delta^{18} \mathrm{O}$ variation observed in BS15 and BS14 would indicate an average temperature fluctuation of at least $\pm 10^{\circ} \mathrm{C}$ during the last $5 \mathrm{ka}$, if calcite precipitated under equilibrium conditions. This is unrealistic for the Holocene. Moreover, the Hendy test was performed on three laminae in both stalagmites to test the conditions of precipitation. It indicates the presence of clear isotope fractionation on lamina $\mathrm{H} 3$ of stalagmite $\mathrm{BS} 14$, while the remaining laminae tested in BS14 and BS15 display lower stable isotope variations (Fig. 6). However, the asymmetric lateral enrichment of isotope composition observed in these laminae is also inconsistent with calcite precipitated under equilibrium conditions along a single lamina. Thus, it is likely that the thinness of single laminae did not allow a sufficient sampling resolution resulting in isotopic values biased by cross-contamination. Thus, disequilibrium conditions have been clearly identified only in lamina H3 of stalagmite BS14. Although isotopic fractionation cannot be evaluated with reliability by the Hendy test, a palaeo-environmental signal may still be recorded if disequilibrium fractionation (which results of environmental forcing) and environmental changes act in the same direction on the isotopic ratios.

The relation between $\mathrm{CO}_{2}$ dynamics and speleothem calcite stable isotope ratios has been widely investigated. $\mathrm{CO}_{2}$ loss to the cave atmosphere is a fast process that is already well underway by the time the water drop hits the stalagmite surface (Dreybrodt, 2011). However, when calcite starts precipitating, $\mathrm{CO}_{2}$ is produced and released to the cave atmosphere. When this process occurs from a thin film of fluid, it causes ${ }^{13} \mathrm{C}$ and ${ }^{18} \mathrm{O}$ enrichment of the DIC (dissolved inorganic carbon) in the solution. While the increase of $\delta^{13} \mathrm{C}$ is an irreversible process, $\delta^{18} \mathrm{O}$ ratios can return to equilibrium values through slow isotopic exchange with water in the hydratation/dehydratation processes of $\mathrm{CO}_{2}$ (Affek \& Zaarur, 2014). However, this re-equilibration is an extremely slow process. Dreybrodt \& Scholz (2011) and Hansen et al. (2013) demonstrated how the rate of outgassing is related to the thickness of the water film on speleothems, preventing complete $\delta^{18} \mathrm{O}$ DIC re-equilibration in thin water films. Considering that the occurrence of disequilibrium conditions in DIC isotope ratios is recorded in the precipitating calcite, speleothems forming from thin films of fluid, which are the result of long drip intervals, may experience enriched $\delta^{13} \mathrm{C}$ and $\delta^{18} \mathrm{O}$ values (Mühlinghaus et al., 2007; Riechelmann et al., 2013; Caddeo et al., 2015). Thus, the large fluctuations of $\delta^{13} \mathrm{C}$ and $\delta^{18} \mathrm{O}$ observed in both stalagmites (especially BS14) suggest a probable influence of variations in water-film thickness on both isotope ratios, with ${ }^{13} \mathrm{C}$ and ${ }^{18} \mathrm{O}$ enrichments during periods of low drip rates, reflecting more arid conditions.

To better interpret the dynamics behind stable isotope variations, trace elements and $\delta^{13} \mathrm{C}$ profiles in stalagmite BS15 were compared. There is a strong $(r=0.72 \quad p<0.001)$ positive correlation between $\delta^{13} \mathrm{C}$ and $\mathrm{Mg}$ profiles in BS15 (Fig. 11; Table 2). Considering the $\mathrm{Mg}$ interpretation, as related to precipitation patterns, its covariation with $\delta^{13} \mathrm{C}$ suggests that the latter is a hydrological proxy in this case, where higher values are indicative of drier periods.

\section{Petrography variations and their relation to environmental changes}

\section{Chemical and physical parameters influencing fabric} variation

The dimension of the crystallites forming the identified composite crystals has not been disentangled at the optical microscope level, suggesting the presence of extremely small calcite crystallites arranged in optical continuity within the crystal aggregates to which they belong. This general structure can be referred to as columnar microcrystalline (Frisia et al., 2000; Frisia \& Borsato, 2010; Frisia 2015). According to Frisia (2015), this fabric can be found in temperate regions characterised by seasonal contrast in temperature, precipitation and vegetation activity. The presence of brown laminae, which is believed to be related to organic matter flushing following vegetation dieback (mainly during autumn at mid-latitudes, Frisia et al., 2000), suggests seasonal changes of water discharge. Although the Sarajevo area is not currently affected by a strong seasonality of precipitation, the significant seasonal temperature contrast must play an important role on evapotranspiration, and thus water balance and year-round variations in drip rate, especially when summer periods are synchronous with relatively low precipitation (Fig. 2).

Present-day monitoring of drip sites in the area where the stalagmites were found shows a strong connection with the external environment (Chiarini et al., unpublished data). In particular, higher discharge is found during late autumn to early spring precipitation, while low-to-absent dripping occurs in summer. Therefore, calcite fabric alternation is likely reflecting changes in drip water saturation 
and drip rate, which are related to environmental changes during the second half of the Holocene in the study area.

Stable isotope profiles and trace elements were compared with petrographic changes in order to better understand the factors involved in crystallite changes. Similar trends between fabric-class variations and $\delta^{13} \mathrm{C}$ are visible in both profiles, suggesting the presence of a common factor driving changes in both parameters (i.e., increased calcite porosity and calcite $\delta^{13} \mathrm{C}$; Fig. 4 and 9). Kruskal-Wallis and multiple tests associated with the Bonferroni correction confirmed the presence of a strong link between $\delta^{13} \mathrm{C}$ and fabric sub-types which associates progressively higher isotope ratios with the more porous and impurityrich fabrics; a similar but markedly weaker trend affects the petrography classes $\delta^{18} \mathrm{O}$ composition with progressively higher values from $\mathrm{Ccm}$ to $\mathrm{Sscm}$ and D (Fig. 9).

Considering the interpretation of $\delta^{13} \mathrm{C}$ as a hydrologic proxy, the formation of a particular calcite texture under progressively increased hydrological stress is clear. Petrographic changes induced by variations in drip rate were first reported by Kendall \& Broughton (1978), then subsequently by Frisia et al. (2000) and Frisia \& Borsato (2010); Mühlinghaus et al. (2007) also found that $\delta^{13} \mathrm{C}$ values in speleothem calcite vary with the drip interval. However, this cannot be considered the sole factor triggering changes in calcite stable isotope composition.

The positive correlation between $\mathrm{Mg}$ and $\mathrm{\delta}^{13} \mathrm{C}$, and their negative correlation with $\mathrm{Sr}$, in stalagmite BS15 suggests a possible trace element signature for each petrography class, which was highlighted by the discriminant analyses performed using $\delta^{13} \mathrm{C}, \delta^{18} \mathrm{O}$, $\mathrm{Mg}$, and $\mathrm{Sr}$ as variables (Fig. 10 and 11). Riechelmann et al. (2014) described the role of $\mathrm{Mg}$ in triggering petrographic changes: the $\mathrm{Mg}$ content, which is related to hydrology, likely contributed to the fabric variations in the studied stalagmites contributing in the formation of crystallites presenting a higher density of defect sites.

Another factor that could influence calcite fabric and $\delta^{13} \mathrm{C}$ changes is the mean annual temperature, which causes changes in the vegetation cover and, consequently, in soil $\mathrm{CO}_{2}$ production. However, the studied stalagmites did not grow over periods long enough to experience significant temperature or climate-driven vegetation changes. Thus, it is more plausible to consider hydrological variations as the major factor triggering both $\delta^{13} \mathrm{C}$ and fabric changes, while the impact on seasonality changes in temperature could have played an indirect role in aquifer recharge via evapotranspiration. Over the long term, a marginal role of vegetation cover in influencing $\delta^{13} \mathrm{C}$ ratios cannot be excluded, as these stable isotope variations are not fully explained by hydrological changes in the studied stalagmite. In particular, in BS15 stalagmite, the uppermost $40 \mathrm{~mm}$ show more numerous Th peaks, suggesting increased soil erosion possibly related to anthropic activities on the overlying plateau. The same portion does not display brown lamination, indicating the absence of flushing events and possibly a relatively regular input of detritus load (Fig. 4).

\section{Palaeo-environmental information recorded by calcite fabrics}

It was demonstrated that drip interval played a fundamental role in the type of calcite fabric of the studied stalagmites, and that the $\mathrm{Mg}$ concentration in drip water possibly influenced fabric development: a longer drip interval caused the calcite $\delta^{13} \mathrm{C}$ ratios to increase, which corresponds to lower $\mathrm{Sr}$ and higher $\mathrm{Mg}$ concentration in stalagmite calcite, also resulting in higher defects and smaller-dimension of the calcite crystallites.

At the more detailed level, groups of laminae formed by compact columnar microcrystalline (Ccm) calcite are those characterised by the highest $\mathrm{Sr}$ and lowest $\mathrm{Mg}$ content. These laminae are separated by wavy brown surfaces, which show evidence of local dissolution of the underlying crystal tips and joints, suggesting flushing events carrying colloids (Supplemental Fig. S1). The presence of flattened calcite crystal terminations and cavities within the compact carbonate lamina below the brownish lamination suggest local (at stalagmite tip), organicmatter oxidation following flushing events (organic colloids from the soil zone), which created an acidic environment leading to very localized dissolution (Frisia, 1996). This pattern can be related to a wet season followed by a relatively dry period, before a strong infiltration event (in autumn) causing a massive flushing of organic matter. These conditions are found in Mediterranean-like climate, which is now present in the coastal area of the Balkans (Vreča et al., 2006).

The open columnar microcrystalline fabric $(0 \mathrm{~cm})$ is instead characterised by increased porosity, which suggests a less-regular crystallite stacking related to an increased amount of foreign particles/colloids. These particles may have caused higher crystal defects, possibly inducing a smaller crystallite size. Brown surfaces, where present, are less sharp than in the previous sub-pattern and contain less evidence of dissolution features, suggesting the occurrence of weaker infiltration events. If compared to the Ccm fabric, a slower growth rate can be inferred from the lower $\mathrm{Sr}$ content. The slightly higher $\mathrm{Mg}$ content suggests instead the presence of marginally drier conditions during its formation. The $\delta^{18} \mathrm{O}$ values detected in the IsoFab plot between $\mathbf{O c m}$ and $\mathbf{C c m}$ are comparable and indicate the absence of strong differences in the water film on the tip of the stalagmites. However, slightly drier conditions may have translated into more irregular dripping, triggering the precipitation of this fabric.

The elongated columnar microcrystalline (Ecm) fabric has only been found in the younger portion of stalagmite $\mathrm{BS} 14$, followed by dendritic fabric at the very top of the stalagmite. Its formation possibly occurred under conditions similar to the ones that prevailed during deposition of elongated columnar calcite associated with the influence of impurities (Frisia, 2015). An increasing supply of foreign particles 
is thought to have caused the higher density of crystal defects, and thus the increased porosity. Its $\delta^{13} \mathrm{C}$ and $\delta^{18} \mathrm{O}$ values are higher when compared to $\mathbf{O c m}$ and Ccm, suggesting its formation under thin films of fluid related to a generally drier climate.

The porous columnar microcrystalline (Pcm) calcite, observed in both stalagmites, coincides with higher $\delta^{13} \mathrm{C}$ and $\delta^{18} \mathrm{O}$ values when compared to the Ocm, but with similar values when compared to the Ecm. This fabric is also characterised by lower $\mathrm{Sr}$ and higher $\mathrm{Mg}$ content, indicating, respectively, slower growth rate and drier conditions. Increased summer temperature may have played a role together with increased aridity causing further irregularities in drip rate.

Finally, the stricto sensu microcrystalline (SScm) fabric and the dendritic fabric mainly occur, respectively, in the upper $18 \mathrm{~mm}$ of stalagmite BS15 and in the upper $3 \mathrm{~mm}$ of stalagmite BS14. The first is associated with higher $\delta^{13} \mathrm{C}$ values but $\delta^{18} \mathrm{O}$ values are comparable to those of $\mathbf{P} \mathbf{c m}$. Brown laminae are faint or absent, suggesting the lack of major flushing events and/or lower soil and vegetation activity. The presence of dendritic calcite at the top of BS14, associated with isotopic values comparable to the SScm of the same stalagmite, would also indicate the presence of generally drier conditions (McDermott et al., 1999; Frisia, 2000). The presence of SScm in BS15 would also be in agreement with a less dense vegetation cover on the overlying plateau. In addition, a black layer preserved in both stalagmites close to their top is likely due to a soot coating. It indicates a likely human frequentation of the cave at this time, and thus settlements in the area.

\section{CONCLUSIONS}

In this study, we analysed two Bosnian speleothems using a multiproxy approach and applying the petrography micrologging method proposed in Frisia (2015) to extract robust environmental interpretations. Comparison of stable isotopes, micro-petrography and trace elements has allowed us to identify hydrological changes as the main forcing parameter.

Petrography micrologging of these stalagmites was found to be a useful tool. Its employment is strongly encouraged when calcite precipitation under disequilibrium conditions is suspected. Indeed, this method can represent a powerful instrument for the detection and interpretation of palaeoenvironmental signals in speleothems where stable isotope fractionation under disequilibrium conditions cannot be ruled out. Petrography also helps to better understand the conditions of precipitation. However, calcite pattern variations can be subtle, and are not always readily resolved; sub-type classifications may have to be defined for specific samples. Comparison with other speleothem proxies is always necessary in order to refine the interpretations.

Finally, as petrography becomes more widely used in speleothem research, it will be necessary to ensure consistency in nomenclature, and to avoid the multiplication and redundancies of sub-classification and terminologies. Accordingly, the development of a working group would be highly desirable, facilitated via workshops and an online discussion platform, including a petrographic database.

\section{ACKNOWLEDGMENTS}

We are grateful to the "Gruppo Speleologico Bolognese/Unione Speleologica Bolognese" for the technical help during sampling campaigns in Bosnia, to the "Federazione Speleologica dell'Emilia Romagna" and the "Gruppo Speleologico Faentino" for funding provided and to the Federal Hydrometeorological Institute of Sarajevo for providing historical meteorological data. A special thanks to Emilie Chalmin (Université Savoie Mont-Blanc, France) and Diego Ercole Angelucci (University of Trento, Italy) for the support provided during microscopic observations; Roland Maas (University of Melbourne, Australia) is thanked for the support provided for U-Th dating; Fausto Desalvo (Department of Mathematics, University of Bologna, Italy) for the help provided in the statistical analyses. Finally, we want to thank the reviewers for their constructive comments.

\section{REFERENCES}

Affek H. \& Zaarur S., 2014 - Kinetic isotope effect in $\mathrm{CO}_{2}$ degassing: insight from clumped and oxygen isotopes in laboratory precipitation experiments. Geochimica et Cosmochimica Acta, 142: 319-330.

https://doi.org/10.1016/j.gca.2014.08.005

Banks E.D., Taylor N.M., Gulley J., Lubbers B.R., Giarrizzo J.G., Bullen H.A., Hoehler T.M. \& Barton H.A., 2010 - Bacterial calcium carbonate precipitation in cave environments: a function of calcium homeostasis. Geomicrobiology Journal, 27: 444-454. https://doi.org/10.1080/01490450903485136

Belli R., Frisia S., Borsato A., Drysdale R., Hellstrom J., Zhao J.-X. \& Spötl C., 2013 - Regional climate variability and ecosystem responses to the last deglaciation in the northern hemisphere from stable isotope data and calcite fabrics in two northern Adriatic stalagmites. Quaternary Science Reviews, 72: 146-158.

https://doi.org/10.1016/j.quascirev.2013.04.014

Borsato A., Frisia S., Fairchild I.J., Somogyi A. \& Susini J., 2007 - Trace element distribution in annual stalagmite laminae mapped by micrometer-resolution $X$-ray fluorescence: implications for incorporation of environmentally significant species. Geochimica et Cosmochimica Acta, 71: 1494-1512.

https://doi.org/10.1016/j.gca.2006.12.016

Caddeo G.A., Railsback L.B., De Waele J. \& Frau F., 2015 - Stable isotope data as constraints on models for the origin of coralloid and massive speleothems: the interplay of substrate, water supply, degassing, and evaporation. Sedimentary Geology, 318: 130-141. https://doi.org/10.1016/j.sedgeo.2014.12.008

Cerling T.E., 1984 - The stable isotope composition of modern soil carbonate and its relationship to climate. Earth and Planetary Science Letters, 71: 229-240. https://doi.org/10.1016/0012-821X(84)90089-X

Couchoud I., 2006 - Étude pétrographique et isotopique de spéléothèmes du sud-ouest de la France formés en contexte archéologique - Contribution à la connaissance des paléoclimats du stade isotopique 5. Thèse de doctorat. Université Bordeaux 1, 346 p. 
Couchoud I., 2008 - Les isotopes stables de l'oxygène et $d u$ carbone dans les spéléothèmes: des archives paléoenvironnementales. Quaternaire, 19 (4): 275-291. https://doi.org/10.4000/quaternaire.4532

Daneš J., 1921 - Pećine u kanjonu Prače $i$ okolini Glasinačkog polja. Glasnik Geografskog društva, Beograd, 5: 139-142.

Dorale J.A \& Liu Z., 2009 - Limitations of Hendy test criteria in judging the paleoclimatic suitability of speleothems and the need for replication. Journal of Cave and Karst Studies, 71 (1): 73-80.

Dorale J.A., Gonzalez L.A., Reagan M.K., Pickett D.A., Murrell M.T. \& Baker R.G., 1992 - A high-resolution record of Holocene climate change in speleothem calcite from Cold Water Cave, Northeast Iowa. Science, 258: $1626-1630$.

https://doi.org/10.1126/science.258.5088.1626

Dorale J.A, Edwards R.L., Ito E. \& Gonzalez L.A., 1998 Climate and vegetation history of the mid-continent from 75 to $25 \mathrm{ka}$ : a speleothem record from Crevice Cave, Missouri, USA. Science, 282: 1871-1874.

https://doi.org/10.1126/science.282.5395.1871

Dorale J.E., Edwards R.L. \& Onac B.P., 2002 - Stable isotopes as environmental indicators in speleothems. In: Yuan D. \& Zhang C. (Eds.), Karst processes and the carbon cycle. Final Report of IGCP 379. Geological Publishing House, Beijing: 107-120.

Dreybrodt W., 1988 - Processes in karst systems. Springer, Berlin, 287 p.

https://doi.org/10.1007/978-3-642-83352-6

Dreybrodt W., 2011 - Comments on processes contributing to the isotope composition of ${ }^{13} \mathrm{C}$ and ${ }^{18} \mathrm{O}$ in calcite deposited in speleothems. Acta Carsologica, 40 (2): 233-238. https://doi.org/10.3986/ac.v40i2.8

Dreybrodt W. \& Scholz D., 2011 - Climatic dependence of stable carbon and oxygen isotope signals recorded in speleothems: from soil water to speleothem calcite. Geochimica et Cosmochimica Acta, 75: 734-752. https://doi.org/10.1016/j.gca.2010.11.002

Drysdale R., Paul B.T., Hellstrom J.C., Couchoud I., Greig A., Bajo P., Zanchetta G., Isola I., Spötl C., Baneschi I., Regattieri E. \& Woodhead J.D., 2012 Precise microsampling of poorly laminated speleothems for $U$-series dating. Quaternary Geochronology, 14: 38-47. https://doi.org/10.1016/j.quageo.2012.06.009

Dunn O.J., 1961 - Multiple comparison among means. Journal of the American Statistical Association, 56: 52-64.

https://doi.org/10.1080/01621459.1961.10482090

Fairchild I.J. \& Treble P.C., 2009 - Trace elements in speleothems as recorders of environmental change. Quaternary Science Reviews, 28: 449-468.

https://doi.org/10.1016/j.quascirev.2008.11.007

Fairchild I.J. \& Baker A., 2012 - Speleothem science: from process to past environments. John Wiley \& Sons, Oxford, $450 \mathrm{p}$.

https://doi.org/10.1002/9781444361094

Fairchild I.J., Borsato A., Tooth A.F., Frisia S., Hawkesworth C.J., Huang Y.-M., McDermott F. \& Spiro B., 2000 - Controls on trace element (Sr-Mg) compositions of carbonate cave waters: implications for speleothem climatic records. Chemical Geology, 166: 255-269.

https://doi.org/10.1016/S0009-2541(99)00216-8

Fairchild I.J., Smith C.L., Baker A., Fuller L., Spötl C., Mattey D., McDermott F. \& EIMF, 2006 - Modification and preservation of environmental signals in speleothems. Earth-Science Reviews, 75: 105-153. https://doi.org/10.1016/j.earscirev.2005.08.003
Frisia S., 1996 - Petrographic evidences of diagenesis in speleothems: some examples. Speleochronos, 7: 21-30.

Frisia S., 2015 - Microstratigraphic logging of calcite fabrics in speleothems as tool for palaeoclimate studies. International Journal of Speleology, 44 (1): 1-16. https://doi.org/10.5038/1827-806X.44.1.1

Frisia S. \& Borsato S., 2010 - Chapter 6 - Karst. In: A.J. Van Loon (Ed.), Carbonates in continental settings. Developments in sedimentology. Elsevier, 61: 269-318.

Frisia S., Borsato A., Fairchild I.J. \& McDermott F., 2000 - Calcite fabrics, growth mechanisms, and environments of formation in speleothems from the Italian Alps and Southwestern Ireland. Journal of Sedimentary Research, 70: 1183-1196.

https://doi.org/10.1306/022900701183

Genty D., Blamart D., Ghaleb B., Plagnes V., Causse Ch., Bakalowicz M., Zouari K., Chkir N., Hellstrom J., Wainer K. \& Bourges F., 2006 - Timing and dynamics of the last deglaciation from European and North African $\delta^{13} \mathrm{C}$ stalagmite profiles - comparison with Chinese and South Hemisphere stalagmites. Quaternary Science Reviews, 25 (17-18): 2118-2142.

https://doi.org/10.1016/j.quascirev.2006.01.030

Giesler R., Andersson T., Lövgren L. \& Persson P., 2005 - Phosphate sorption in aluminium- and iron-rich humus soils. Soil Science Society of America Journal, 69: 77-86.

Green S.B., Salkind N.J. \& Akey T.M., 2008 - Using SPSS for Windows and Macintosh: Analysing and understanding data. Prentice Hall, New Jersey.

Hansen M., Dreybrodt W. \& Scholz D., 2013 - Chemical evolution of dissolved inorganic carbon species flowing in thin water films and its implications for (rapid) degassing of $\mathrm{CO}_{2}$ during speleothem growth. Geochimica et Cosmochimica Acta, 107: 242-251. https://doi.org/10.1016/j.gca.2013.01.006

Hellstrom J., McCulloch M. \& Stone J., 1998 - A detailed 31,000-year record of climate and vegetation change, from the isotope geochemistry of two New Zealand speleothems. Quaternary Research, 50 (2): 167-178. https://doi.org/10.1006/qres.1998.1991

Hellstrom J., 2006 - U-Th dating of speleothems with high initial ${ }^{230}$ Th using stratigraphical constraint. Quaternary Geochronology, 1: 289-295.

https://doi.org/10.1016/j.quageo.2007.01.004

Hendy C.H., 1971 - The isotopic geochemistry of speleothems-I. The calculation of the effects of different modes of formation on the isotopic composition of speleothems and their applicability as palaeoclimatic indicators. Geochimica et Cosmochimica Acta, 35: 801-824.

https://doi.org/10.1016/0016-7037(71)90127-X

Huang Y. \& Fairchild I.J., 2001 - Partitioning of $\mathrm{Sr}^{2+}$ and $\mathrm{Mg}^{2+}$ into calcite under karst-analogue experimental conditions. Geochimica et Cosmochimica Acta, 65: 47-62. https://doi.org/10.1016/S0016-7037(00)00513-5

Huang Y., Fairchild I.J., Borsato A., Frisia S., Cassidy N.J., McDermott F. \& Hawkesworth C.J., 2001 - Seasonal variations in $\mathrm{Sr}, \mathrm{Mg}$ and $\mathrm{P}$ in modern speleothems (Grotta di Ernesto, Italy). Chemical Geology, 175: 429-448. https://doi.org/10.1016/S0009-2541(00)00337-5

Kendall A.C. \& Broughton P.L., 1978 - Origin of fabrics in speleothems composed of columnar calcite crystals. Journal of Sedimentary Research, 48: 519-538.

Kennett D.J., Breitenbach F.M., Aquino V.V., Asmerom Y., Awe J., Baldini J.U.L., Bartlein P., Culleton B.J., Ebert C., Jazwa C., Macri M.J.,Marwan N., Polyak V., Prufer K.M., Ridley H.E., Sodemann H., Winterhalder B. \& Haug G.H. (2012) - Development and disintegration of Maya political systems in response to climate change. Science, 338: 788-791. https://doi.org/10.1126/science.1226299 
Lachniet M.S., 2009 - Climatic and environmental controls on speleothem oxygen-isotope values. Quaternary Science Reviews, 28: 412-432. https://doi.org/10.1016/j.quascirev.2008.10.021

Mattey D., Fairchild I.J., Atkinson T.C., Latin J.P., Ainsworth M. \& Durell R., 2010 - Seasonal microclimate control of calcite fabrics, stable isotopes and trace elements in modern speleothems from St. Michaels Cave, Gibraltar. In: Pedley HM \& Rogerson M. (Eds.), Tufas and speleothems: unraveling the microbial and physical controls. Geological Society of London Special Publications, 336: 323-344.

https://doi.org/10.1144/sp336.17

McDermott F., 2004 - Paleo-climate reconstruction from stable isotope variations in speleothems: a review. Quaternary Science Reviews, 23 (7): 901-918. https://doi.org/10.1016/j.quascirev.2003.06.021

McDermott F., Frisia S., Huang Y., Longinelli A., Spiro B., Heaton T.H.E., Hawkesworth C.J., Borsato A., Keppens E., Fairchild I.J., van der Bor K., Verheyden S. \& Selmo E., 1999 - Holocene climate variability in Europe: Evidence from $\delta^{18} \mathrm{O}$, textural and extension-rate variations in three speleothems. Quaternary Science Reviews, 18: 1021-1038.

https://doi.org/10.1016/S0277-3791(98)00107-3

Mickler P.J., Stern L.A. \& Banner J.L., 2006 - Large kinetic isotope effects in modern speleothems. Geological Society of America Bulletin, 118 (1-2): 65-81.

https://doi.org/10.1130/B25698.1

Milanolo S., Preti N. \& Cella G., 2013 - Govještica Cave Prača Canyon, BIH. Naš Krš Sarajevo, 23: 43.

Mucci A. \& Morse J.W., 1990 - Chemistry of lowtemperature abiotic calcites: experimental studies on coprecipitation, stability, and fractionation. Reviews in Aquatic Science, 3: 217-254.

Mühlinghaus C., Scholz D. \& Mangini A., 2007 - Modelling stalagmite growth and $\delta^{13} \mathrm{C}$ as a function of drip interval and temperature. Geochimica et Cosmochimica Acta, 71: 2780-2790.

https://doi.org/10.1016/j.gca.2007.03.018

Plagnes V., Causse C., Genty D., Paterne M. \& Blamart D., 2002 - A discontinuous climatic record from 187 to $74 \mathrm{ka}$ from a speleothem of the Clamouse Cave (South of France). Earth and Planetary Science Letters, 201: 87-103.

https://doi.org/10.1016/S0012-821X(02)00674-X

Plummer L.N., 1977 - Defining reactions and mass transfer in part of the Floridan aquifer. Water Resources Research, 13: 801-812.

https://doi.org/10.1029/WR013i005p00801

Ridley H.E., Asmerom Y., Baldini J.U.L., Breitenbach S.F.M., Aquino V.V., Prufer K.M., Culleton B.J., Polyak V., Lechleitner F.A., Kennett D.J., Zhang M., Marwan N., Macpherson C.G., Baldini L.M., Xiao T., Peterkin J.L., Awe J. \& Haug G.H. (2015) - Aerosol forcing of the position of the intertropical convergence zone since $A D$ 1550. Nature Geoscience, 8: 195-200.

https://doi.org/10.1038/ngeo2353
Riechelmann D.F.C., Deininger M., Scholz D., Riechelmann S., Schröder-Ritzrau A., Spötl C., Richter D.K., Mangini A \& Immenhauser A., 2013 - Disequilibrium carbon and oxygen isotope fractionation in recent cave calcite: Comparison of cave precipitates and model data. Geochimica et Cosmochimica Acta, 103: 232-244.

https://doi.org/10.1016/j.gca.2012.11.002

Riechelmann S., Schröder-Ritzrau A., Wassenburg J.A., Schreuer J., Richter D.K., Riechelmann D.F., Terente M., Constantin S., Mangini A. \& Immenhauser A., 2014 - Physicochemical characteristics of drip waters: influence on mineralogy and crystal morphology of recent cave carbonate precipitates. Geochimica et Cosmochimica Acta, 145: 13-29.

https://doi.org/10.1016/j.gca.2014.09.019

Roberts M.S., Smart P.L. \& Baker A., 1998 - Annual trace element variations in a Holocene speleothem. Earth and Planetary Science Letters, 154: 237-246. https://doi.org/10.1016/S0012-821X(97)00116-7

Sartori G., Mancabelli A., Wolf U. \& Corradini F., 2005 - Atlante dei suoli del Parco Naturale Adamello-Brenta. Monografie II, Museo Tridentino di Scienze Naturali, Trento, 239 p.

Spötl C. \& Mangini A., 2002 - Stalagmite from the Austrian Alps reveals Dansgaard-Oeschger events during isotope stage 3: Implications for the absolute chronology of Greenland ice cores. Earth and Planetary Science Letters, 203 (1): 507-518. https://doi.org/10.1016/S0012-821X(02)00837-3

Srejović D., 1994 - Kulture gvozdenog doba na tlu Srbije, Istorija srpskog naroda I, Srpska književna zadruga, Beograd.

Thornthwaite C.W. \& Mather J.R., 1957 - Instruction and tables for computing potential evapotranspiration and the water balance. Publications in climatology, Drexel Institute Technology, Philadelphia, 10, 254 p.

Treble P.C., Chappell J. \& Shelley J.M.G., 2005 - Complex speleothem growth processes revealed by trace element mapping and scanning electron microscopy of annual layers. Geochimica et Cosmochimica Acta, 69 (20): 4855-4863. https://doi.org/10.1016/j.gca.2005.06.008

Treble P., Shelley J.M.G. \& Chappell J., 2013 - Comparison of high resolution sub-annual records of trace elements in a modern (1911-1992) speleothem with instrumental climate data from southwest Australia. Earth and Planetary Science Letters, 216: 141-153. https://doi.org/10.1016/S0012-821X(03)00504-1

Usdowski E. \& Hoefs J., $1990-$ Kinetic ${ }^{13} \mathrm{C} /{ }^{12} \mathrm{C}$ and ${ }^{18} \mathrm{O} /{ }^{16} \mathrm{O}$ effects upon dissolution and outgassing of $\mathrm{CO}_{2}$ in the system $\mathrm{CO}_{2}-\mathrm{H}_{2} \mathrm{O}$. Chemical Geology, 80: 109-118.

Vreča P., Krajcar Bronić I., Horvatinčić N. \& Barešić J., 2006 - Isotopic characteristics of precipitation in Slovenia and Croatia: comparison of continental and maritime stations. Journal of Hydrology, 330: 457-469. https://doi.org/10.1016/j.jhydrol.2006.04.005

Woodhead J.D., Hellstrom J., Hergt J.M., Greig A. \& Maas R., 2007 - Isotopic and elemental imaging of geological materials by laser ablation inductively coupled plasmamass spectrometry. Geostandards and Geoanalytical Research, 31 (4): 331-343. https://doi.org/10.1111/j.1751-908x.2007.00104.x 